1 Diagenetic evolution of lower Jurassic platform carbonates flanking the

2 Tazoult salt wall (Central High Atlas, Morocco)

3

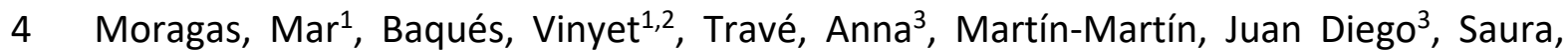
5 Eduard $^{1,4}$, Messager, Gregoire ${ }^{5}$, Hunt, David $^{5}$, Vergés, Jaume $^{1}$

6 *corresponding author: mar.moragas.rodriguez@gmail.com

7

81 Group of Dynamics of the Lithosphere (GDL), Institute of Earth Sciences Jaume Almera, 9 ICTJA-CSIC, Lluís Solé i Sabarís s/n, 08028 Barcelona, Spain

102 Bureau of Economic Geology, Jackson School of Geosciences, The University of Texas 11 at Austin, University Station Box X, Austin, TX 78713-8924, USA

123 Dept. Mineralogia, Petrologia i Geologia Aplicada, Facultat de Ciències de la Terra, 13 Universitat de Barcelona (UB), Martí i Franqués s/n, 08028 Barcelona, Spain

144 Lithica SCCL, Santa Coloma de Farners, Spain

155 EQUINOR Research Centre Bergen, Statoil A.S.A., Sandsliveien 90, 5020 Bergen, 16 Norway 
This study is funded by Equinor Research Centre, Bergen (Norway), by the Spanish Ministry of Education and Science (MEC) through the process Intramural Especial (CSIC 201330E030), Alpimed (PIE-CSIC-201530E082), CSIC-FSE 2007-2013 JAE-Doc postdoctoral research contract (E.S.), as well as the Group of Sedimentary research of the University of Barcelona (UB) (CGL 2015-66335-C2-1-R and SGR2017-824). The isotopic and electron microprobe analyses were carried out at 'Centres Científics i Tecnologics' of the Universitat de Barcelona. This paper benefited from constructive reviews from Fadi Nader, Lars Reuning, Mohamed Gouiza and Editor Craig Magee.

\section{CONFLICT OF INTEREST SECTION}

No conflict of interest declared

\section{ABSTRACT and KEYWORDS}

Platform carbonates diagenesis in salt basins could be complex due to potential alterations of fluids related and non-related to diapirism. This paper presents the diagenetic history of the Hettangian to Pliensbachian platform carbonates from the Tazoult salt wall area (central High Atlas, Morocco). Low structural relief and outcrop conditions allowed to define the entire diagenetic evolution occurred in the High Atlas diapiric basins since early stages of the diapiric activity up to their tectonic inversion. Precipitation of dolomite and calcite from both warmed marine-derived and meteoric fluids characterised diagenetic stages during Pliensbachian, when the carbonate platforms were exposed and karstified. Burial diagenesis occurred from Toarcian to Middle Jurassic, due to changes of salt-induced dynamic related to increase in siliciclastic input, fast diapir rise and rapid burial of Pliensbachian platforms. During this stage, the diapir acted as a physical barrier for fluid circulation between the core and the flanking sediments. In the carbonates and breccias flanking the structures, dolomite and calcite 
precipitated from basinal brines, whereas carbonate slivers located in the core of the structure, were affected by the circulation of Mn-rich fluids. The final diagenetic event is characterised by the income of meteoric fluids into the system during uplift caused by Alpine orogeny. These results highlight the relevant influence of diapirism on the diagenetic modifications in salt-related basins in terms of diagenetic events and involved fluids.

Keywords: Diagenesis, Basin fluids, Platform carbonates, Salt tectonics, Diapiric basins

\section{INTRODUCTION}

The formation of carbonate platforms associated with salt diapirs are generally complex due to the interplay between salt tectonics, vertical movements of the substrate and sea-level changes (e.g. Bosence, 2005; Giles et al., 2008). In a similar way, the diagenetic evolution of platform carbonates fringing salt diapirs may be complex as fluid flow pathways and fracturing patterns can differ substantially from intervening minibasins (Fischer et al., 2013; Magri et al., 2008; Posey and Kyle, 1988; Reuning et al., 2009; Smith et al., 2012). Major controls on diagenesis in such settings include localised uplift, fracturing, brecciation, and focused fluid flow along the diapirs flanks, among others. The understanding of the interaction between these elements is essential in the analysis of reservoir quality linked to diagenesis (Beavington-Penney et al., 2008; Ghazban et al., 2010; McManus et al., 1988; Schoenherr et al., 2009). The referenced studies however are mostly handicapped by the lack of continuous outcrops or well data availability. In this regard, the continuous and excellent exposures of the lower Jurassic carbonates flanking the Tazoult salt wall (central High Atlas of Morocco) represent a unique opportunity to analyse the diagenetic evolution and its implications in modifying the carbonate properties through time.

The study of the geometry and evolution of diapiric structures that were active from Early to Middle Jurassic times in the central High Atlas, and their interaction with the flanking rocks, has been addressed in later years (Bouchouata et al., 1995; Ettaki et al., 2007; Martín-Martín et al., 2017; Michard et al., 2011; Moragas et al., 2018; Saura et al., 2014; Teixell et al., 2017; Vergés et al., 2017). The presented study of diagenesis in the 
Tazoult salt wall is part of a prolonged work of our group in the Central High Atlas, detailed below, in which extensive field work and remote sensing mapping was carried out. Integrated analysis of both structural geology (Saura et al., 2014; Vergés et al., 2017) and sedimentology of the lower-middle Jurassic mixed carbonate-clastic system (Joussiaume, 2016; Malaval, 2016) allowed the discovery of well-preserved and unequivocal halokinetic depositional sequences and to highlight the role of salt tectonics as an additional control on the evolution of the Central High Atlas rift basin during Early and Middle Jurassic times. Concerning the Tazoult salt wall, the study of stacks of halokinetic sequences with both carbonate and mixed carbonate/clastic deposits along the structure indicated its evolution as a $20-\mathrm{km}$ long, NE-SW trending salt wall forming a structural and sedimentary high for at least 20 Myr from Pliensbachian to Bajocian times (Martín-Martín et al., 2017). This first study was complemented through subsidence and thermal analysis evaluated using vitrinite data (Moragas et al., 2018) and analogue models (Moragas et al., 2017). Results indicated a close relationship between high subsidence rates and salt-related areas due to two competing mechanisms: tectonic extension and salt withdrawal. Despite the above mentioned literature, there is a lack of studies focusing on the diagenetic evolution of the rocks flanking such diapirs, and thus their analysis needs proper attention. The current erosion of the Tazoult salt wall, as well as most of the central High Atlas diapirs, allows the exposure of structural levels that are buried beneath kilometre-thick Mesozoic successions in other localities of the High Atlas. The excellent exposure of old stratigraphic units and the limited deformation related to the Alpine compression, made the Tazoult salt wall an excellent field analogue to evaluate the complexity of the diagenetic evolution of platform carbonates since early stages of the diapiric activity.

This work aims to: (i) characterise the diagenetic alterations affecting the Early Jurassic platform carbonates flanking the Tazoult salt wall, (ii) constrain the type, origin and pathways of the fluids that drive such alterations, and (iii) construct a model of the Tazoult salt wall that illustrates the diagenetic evolution of the overlying platform carbonates through time, from the onset of diapirism to the Alpine compression. The results of this study will ultimately provide information about how diapiric activity could influence diagenetic overprinting and fluid circulation in stratigraphic levels that are 
often not accessible. The presented study represents an analogue for similar diapiric structures in other salt basins. Moreover, it contributes to a better understanding of reservoir quality in platform carbonates attached to salt diapirs, which typically are target for geological resources exploration as oil, gas or ore deposits.

\section{GEOLOGICAL SETTING}

The High Atlas of Morocco is a double verging fold-and-thrust belt that resulted from the tectonic inversion of the Triassic-Jurassic rift basin during the Alpine Orogeny (Arboleya et al., 2004; Beauchamp et al., 1999; Frizon de Lamotte et al., 2000; Edgard Laville et al., 1977; E. Laville et al., 1992; Mattauer et al., 1977; Piqué et al., 2000; Teixell et al., 2003; Tesón et al., 2008). The central part of the High Atlas is characterised by the presence of elongated and wide synclines of Early and Middle Jurassic sediments separated by ENE-WSW-trending thrusts and thrusted anticlines (Fig. 1). The core of the anticlines are composed of Triassic evaporite-bearing shales and sandstones intruded by Middle to Late Jurassic magmatic bodies (Frizon de Lamotte et al., 2008; Hailwood et al., 1971; Jossen et al., 1990; E. Laville et al., 1982). These anticlines were recently interpreted as diapirs that started forming and were active during, at least, Early and Middle Jurassic times (Bouchouata, 1994; Bouchouata et al., 1995; Ettaki et al., 2007; Martín-Martín et al., 2017; Michard et al., 2011; Moragas et al., 2018; Saura et al., 2014; Teixell et al., 2017; Vergés et al., 2017).

The Tazoult salt wall corresponds to a NE-SW-trending elongated four-way closure salt wall slightly oblique to the more common ENE-WSW structural alignments of the central High Atlas (Fig. 1B). The diapir is about $20 \mathrm{~km}$ long and 0.6 to $3 \mathrm{~km}$ wide. Its core is formed by Upper Triassic red beds and basalts from the Central Atlantic Magmatic Province (CAMP), Middle Jurassic intrusions, and slivers of Hettangian-Lower Sinemurian carbonates (Aït bou Oulli Fm.) (Fig. 2). The Tazoult salt wall is bounded in both flanks by sub-vertical Pliensbachian platform carbonates that grades vertically, and away from the flanks, to Late Pliensbachian-Early Aalenian siliciclastic-carbonate mixed deposits of the Zawyat Ahançal group (Fig. 2). Well-preserved halokinetic sequences on the flanks of the Tazoult salt wall show thinning, onlaps, and truncations, documenting 
the diapiric activity from Early to Middle Jurassic times (Bouchouata, 1994; Bouchouata et al., 1995; Martín-Martín et al., 2017). Shallow marine Late Aalenian-Bajocian platforms carbonates were deposited as a relative uniform unit across the area. These carbonates do not display any evidence of salt tectonic activity during their deposition and thus they recorded that the Tazoult diapir became inactive at that time. Despite the Sinemurian sediments do not crop out in the studied area (Fig.2), they are expected to be located beneath Pliensbachian deposits as is reported in other localities of the central High Atlas (Mehdi et al., 2003; Poisson et al., 1998; Wilmsen et al., 2008). The evolution of the Tazoult salt wall reported by Martín-Martín et al. (2017) is considered as the structural framework for the diagenetic study presented here. These authors analysed in detail the halokinetic sequences in both flanks of the Tazoult salt wall by using remote sensing mapping and field data and presented several cross-sections along the salt structure. Base on their observations, Martín-Martín et al. (2017) define six different stages of diapiric activity and determine the relationship between sedimentation rate and diapir rise rate. According to later authors, the Tazoult salt wall underwent two major stages of diapir activity in the Late Pliensbachian and Toarcian to Aalenian times. Halokinesis was followed by the partial fossilization of the diapir during the Bajocian, and the squeezing and welding of the structure during the Alpine compression.

This study focuses on the Hettangian-Lower Sinemurian carbonates (Aït bou Oulli Fm.) embedded within the Tazoult diapir core, and the two Pliensbachian platform carbonate units (Jbel Choucht Fm. and Aganane Fm.) that are separated by a sedimentary breccia (Talmest-N'Tazoult Fm.). The Aït bou Oulli Fm. appears in discontinuous outcrops on the NW flank of the diapir but they are dominantly distributed as allochthonous slivers $(<5 \mathrm{~m}$ to $3 \mathrm{~km}$ ) embedded within Upper Triassic clays and basalts of the diapir core (Fig. 2C and 3). These Hettangian-Lower Sinemurian carbonates represent the earliest marine sediments deposited after the Triassic evaporites and consist of centimetre-thick beds of light to dark grey micritic limestones and dolostones with algal lamination (Ibouh et al., 2001; Jossen et al., 1990; Martín-Martín et al., 2017; Mehdi et al., 2003).

The Jbel Choucht Fm. carbonate platform, which is up to 250 meters thick, is composed of 0.3 to 2 meter-thick and dark to light grey limestones beds rich in gastropods, bivalves and oncolites. Typically, the large bivalves (Lithiotis $s p$.) form floatstones to rudstones 
limestone textures that characterise platform margin deposits (Bouchouata, 1994;

Bouchouata et al., 1995; Jossen et al., 1990; Joussiaume, 2016; Malaval, 2016; Martín-

Martín et al., 2017). In the southern flank of the Tazoult salt wall (Fig. 2D), the Jbel Choucht Fm. hosts zinc and lead Mississippi Valley type (MVT) deposits (Aguerd $\mathrm{n}$ 'Tazoult mine). Such type of mineralization is also described in other salt structures of the central High Atlas (Mouttaqi et al., 2011; Rddad et al., 2018).

The top of the Jbel Choucht platform is karstified and overlaid by the Talmest-n'Tazoult $\mathrm{Fm}$. The basal part of this formation is characterised by red clay matrix breccias with Triassic and Jbel Choucht limestones clasts that passes vertically to conglomerates, sandstones, clays and marls arranged in 0.5 to 2-meter-thick beds (Martín-Martín et al., 2017). The Talmest-n'Tazoult Fm. passes vertically and laterally to the Aganane Fm. that constitutes the upper platform carbonates deposited during Pliensbachian times on both flanks of the Tazoult salt wall. The Aganane formation consists of well-bedded oncolithic limestones, black mudstones and marls with local large bivalve-rich (Lithiotis sp.) levels deposited in inner platform and lagoon settings (Bouchouata et al., 1995; Fraser et al., 2004; Lee, 1983; Martín-Martín et al., 2017).

\section{METHODOLOGY}

Fifty-five samples were collected from the Hettangian-Lower Sinemurian (Aït bou Oulli Fm.) slivers and Pliensbachian platform carbonates (Jbel Choucht and Aganane formations) and breccias (Talmest-n'Tazoult Fm.) flanking the Tazoult salt wall. These samples, including host rock, veins and karstic fillings, were selected to identify lithology, sedimentary components, diagenetic phases and their crosscutting relationships. Sixtyfive thin sections were stained with Alizarine Red-S and potassium ferricyanide to distinguish calcite and dolomite from their ferroan equivalents (Dickson, 1966). The standard thin sections were prepared and analysed using transmitted light and cathodoluminescence microscopy. Cathodoluminescence petrography was carried out on a Technosyn Cold Cathodoluminescence equipment (model 8200 Mkll), with operating conditions at $15-18 \mathrm{Kv}$ and $150-350 \mu \mathrm{A}$ gun current. Stable isotopy and 
193

characterise the type and origin of the fluids involved in the diagenetic alterations of the studied intervals (see data in supplementary material I and II). Seventy-one samples of depositional and diagenetic calcite and dolomite phases were obtained for carbon- and oxygen-isotope analysis using a microdrill to extract $60 \pm 10 \mu \mathrm{g}$ of powder directly from polished slabs. The calcite and dolomite powdered was reacted with $103 \%$ phosphoric acid for $10 \mathrm{~min}$ at 90 ․ The $\mathrm{CO}_{2}$ was analysed using an automated Kiel Carbonate Device attached to a Thermal Ionization Mass Spectrometer Thermo Electron (Finnigan) MAT-252. The isotopic results have a precision of $\pm 0.02 \%$ ofor $\delta^{13} \mathrm{C}$ and $\pm 0.04 \%$ o for $\delta^{18} \mathrm{O}$. The results were corrected using the standard technique (Claypool et al., 1980; Moore et al., 2013) and are expressed in \%o with respect to the VPDB standard. Carbon-coated and double polished thin-sections of selected samples were used to analyse minor and trace element concentrations in a CAMECA SX-50 electron microprobe. The microprobe was operated using $20 \mathrm{kV}$ of excitation potential, a current intensity of $15 \mathrm{nA}$ and a beam diameter of $10 \mu \mathrm{m}$. The detection limits are 99 ppm for Mn, 144 ppm for Fe, 386 ppm for $\mathrm{Mg}, 89 \mathrm{ppm}$ for Sr ppm and $497 \mathrm{ppm}$ for Ca. Precision on major element analyses averaged $6.32 \%$ standard error at 3 sigma confidence levels.

\section{FIELD AND PETROGRAPHIC OBSERVATIONS}

In this section, we describe the distribution of all the diagenetic products in the different studied units, i.e. Aït bou Oulli Fm. (Hettangian-Lower Sinemurian carbonate slivers), Jbel Choucht Fm. (Pliensbachian platform carbonates), Talmest-N'Tazoult Fm. (Pliensbachian sedimentary breccias) and Aganane Fm. (Pliensbachian platform carbonates).

\subsection{Aït bou Oulli Fm. (Hettangian-Lower Sinemurian platform carbonates)}

The Hettangian-Lower Sinemurian carbonate slivers are composed of dolomicrites and dolosparites with no remnants of the original limestones (Fig. $3 \mathrm{~A}$ and $\mathrm{B}$ ). The dolomicrites (D1) form fine to very fine crystals with dull orange luminescence under cathodoluminescence $(\mathrm{CL})$. D1 is partially replaced, and thus predates, replacive 
dolomite 1 (RD1) that form coarser crystal mosaics (dolosparites). RD1 are characterised by anhedral to euhedral crystals with red bright luminescence (Fig. $3 C$ and D).

The Aït bou Oulli slivers show brecciated fracture corridors, up to $50 \mathrm{~cm}$ wide, which include several generations of calcite cements (Fig. 3E). The outer part of the corridors is characterised by a crackle texture that changes to mosaic breccia in the core. The later corresponds to a more developed cataclasites (Fig.3E and F). The breccias include clasts of the Ait Bou Oulli Fm. and fragments of calcite and fluorite cements (CC4-S and FI). The Aït bou Oulli Fm. clasts are subangular with size ranging from less than $1 \mathrm{~mm}$ to $3 \mathrm{~cm}$. Calcite cement CC4-S clasts consist of translucent subhedral calcite crystals with dull orange luminescence $\mathrm{CL}$ pattern, and fluorite clasts (FI) consist of subhedral fluorite crystals with purple luminescence (Fig. 3G and H). Calcite cement CC6 engulfs, and thus post-dates, clasts of $\mathrm{D} 1, \mathrm{RD} 1, \mathrm{CC} 4$ and $\mathrm{Fl}$. CC6 shows bright orange luminescent subhedral to euhedral crystals featuring blocky texture.

233 The edge of the Hettangian-Lower Sinemurian carbonate slivers (i.e, sliver-diapir contact) is commonly brecciated, being the resulting rock classified as a cemented rubble floatbreccia sensu Morrow (1982). These breccias are mainly constituted by Aït bou Oulli Fm. clasts floating in a red clay matrix with a high content of quartz and hematite. Host rock clasts are frequently calcitized (CD1), forming anhedric to euhedric crystals with dull orange luminescence. The clasts of the floatbreccias are cemented, and thus post-dated by non-luminescent calcite cement $\mathrm{CC} 7$ with orange bright zonation (CC7, Fig. 3C and D). The breccia is partially dissolved to form a highly porous honeycomb-like texture at outcrop ('carneugle').

4.2. Jbel Choucht Fm. (Pliensbachian platform carbonates) and Talmest-n'Tazoult Fm. (Pliensbachian breccias)

244 The base of the Jbel Choucht Fm. carbonates (C2), from the diapir-platform contact up 245 to 10 meters away, is dolomitized, and thus post-dated by replacive dolomite 1 (RD1) 246 (Fig. 4A). RD1 replaces all components (non-fabric selective) and is characterised by well247 developed euhedral crystals (up to $60 \mu \mathrm{m}$ ) with a bright orange luminescence (Fig. 5A 248 and B). The degree of replacement decreases up sequence, and thus the depositional 
texture made of $\mathrm{C} 2$ and an early generation of interparticle non-luminescent calcite cement 1 (CC1) appear only partially dolomitized. Dolomitized and non-dolomitized Jbel Choucht carbonates show $\mathrm{mm}$-scale vuggy pores that are completely occluded, and thus post-dated by calcite cement CC3 (Fig. 5A and B). CC3 appear as bladed (CC3a) and mosaic fabric (CC3b) calcite crystals in the outer and inner parts of the vugs, respectively. CC3 shows a zoned non-luminescent to bright orange luminescence under CL. Fractures affecting the RD1 crystal mosaics and all previously described diagenetic alterations are completely filled, and thus post-dated, by subhedric calcite cement 4 (CC4-F) composed of translucent subhedral calcite crystals with dull orange luminescence CL pattern (Fig. 5). Calcite cement CC4-F shows similar petrographic characteristics (texture and CL pattern) than calcite cement CC4-S observed as a clast component of breccias in the Aït bou Oulli slivers.

The top of the Jbel Choucht platform carbonates is karstified and characterised by $\mathrm{cm}$ to dm-scale dissolution vugs filled by karstic sediments (Fig. 4B, C and D). Two types of fillings are differentiated, a karstic sediment 1 (CS1) made up of very fine grain orange sand sediment with bright orange luminescence under $\mathrm{CL}$, and a karstic sediment 2 (CS2) made of fine grain red sediment with dull reddish luminescence (Fig. 5). Vug porosity in karstic sediment is partially occluded, and thus post-dated by calcite cement 3 (CC3, Fig. $5 A$ and $B$ ). The karstic fillings are replaced, and thus post-dated by replacive dolomite 3 (RD3) that show a characteristic orange bright luminescence (Fig. $5 \mathrm{G}$ and H). The remaining porosity after CC3 precipitation is partially cemented by well-developed coarse crystalline saddle dolomite (SD1), which show orange dull to bright luminescence $\mathrm{CL}$ pattern. Saddle dolomite SD1 is post-dated by (i) the precipitation of calcite cement CC5 in fractures, and (ii) by its calcitization by calcitized dolomite 1 (CD1) (Fig. 5C, D, E and F).

The Talmest-n'Tazoult Fm., which overlies the karstified and eroded surface developed at the top of Jbel Choucht carbonates, consists of breccias made of sub-angular to angular cm-scale clasts of Jbel Choucht carbonates and Triassic siltstones and sandstones with a red fine grain matrix equivalent to the karstic sediments (CS1 and CS2) (Fig 4D). As occurred in Jbel Choucht Fm., the vug porosity observed in the Talmest$\mathrm{n}^{\prime}$ Tazoult Fm. is occluded by the precipitation of calcite cement CC3. Fracture porosity 
affecting CS1, CS2, RD3 and SD1 in both Jbel Choucht and Talmest-n'Tazoult Fm. is filled and thus post-dated by calcite cements 4 and 5 (CC4-F and CC5). CC4 is distinguished by its characteristic bright orange luminescence (Fig. $5 \mathrm{~L}$ and M) whereas CC5 typically form drusy mosaics made of equant spar calcite crystals with zoned luminescence ranging from dull to bright orange (Fig. $5 \mathrm{~J}$ and $\mathrm{K}$ ).

\subsection{Aganane Fm. (Pliensbachian platform carbonates)}

286

The primary interparticle porosity within the Aganane Fm. host carbonates (C3) is filled with calcite cements 2 and 3 (CC2 and CC3). CC2 appears rimming most depositional components and is characterised by a red bright luminescence (Fig. 6B and 6C). CC3 fills the remaining interparticle porosity after $\mathrm{CC} 2$, and is characterised by mosaic fabric and zoned non-luminescent to bright orange luminescent calcite crystals. The top of the Aganane platform carbonates is slightly karstified, forming small-scale cavities filled with ochre karstic sediment 3 (CS3) that show a red dull luminescence. The Aganane Fm. limestones (C3) are partially dolomitized, and thus post-dated, by non-luminescent replacive dolomite 2 (RD2). Fractures within the karstified and partially dolomitized Aganane Fm. are filled, and thus post-dated, with saddle dolomite 1 (SD1) and calcite cements 4 and 5 (CC4-F and CC5). SD1 crystals are calcitized (CD1) (Fig. 6D).

\subsection{Relative timing of the diagenetic features}

Based on crosscutting relationship, both in outcrop and in thin section, we established the relative chronology of the diagenetic products observed in the Hettangian-Lower Sinemurian Aït bou Oulli Fm. slivers and Pliensbachian platform carbonates and breccias flanking the Tazoult salt wall (Jbel Choucht, Talmest-n'Tazoult and Aganane formations).

Pre-Stage 1 corresponds to the formation of the dolomite D1 in the Ait Bou Oulli formation (Fig. 7). Stage 1 includes the deposition of the Jbel Chouch Fm. (C2) and the precipitation of calcite cement CC1 in interparticle porosity of these limestones. Partial dolomitization of Aït bou Oulli Fm. slivers and base of Jbel Choucht Fm. occurred during this stage, but post-dated the deposition of Jbel Choucht limestones (Fig. 7). 
In the units flanking the diapiric structure, stage 2 correspond to the kasrtification of the top of the Jbel Choucht platform carbonates, the deposition of the Talmest-n'Tazoult breccias and the deposition of karstic sediments (CS1 and CS2) (Fig. 7). Stage 3 and 4 are characterised by the deposition of the carbonates of Aganane Fm., the precipitation of

$311 \mathrm{CC2}$, the local karstification of the uppermost part of this formation accompanied with the deposition of karstic sediment CS3, and the partial dolomitization of this carbonates by RD2 (Fig. 7). Stage 5 is characterised by the dolomitization of karstic sediment at the top of Jbel Chouch Fm. by RD3, and the precipitation of saddle dolomite SD1 and calcite cement CC4-F in fractures affecting all the units flanking the Tazoult salt wall. Stage 6 represents the precipitation of CC5 followed the precipitation of CC4-F (Fig. 7).

In the Hettangian slivers, the chronology of events is less well constrained, as calcite cement CC4-S and fluorite could form at any time between the dolomitization that results in replacive dolomite RD1 (Stage 1 ) and the precipitation of the calcite cement CC6 (Stage 6) (Fig. 7). All studied units, both in the diapir core and flanking the structure, include calcitized dolomite (CD1) and calcite cement CC7 formed during the last stage of diagenesis (Stage 7, Fig. 7).

\section{GEOCHEMISTRY}

324 The elemental and isotopic composition analyses of the Aït bou Oulli Fm. (D1) were not possible to obtained due to the overprinting by the replacive dolomite RD1. Contrarily, the Pliensbachian carbonate of Jbel Choucht and Aganane formations show similar elemental composition but different stable isotope signal. The Jbel Choucht Fm. carbonates (C2) are characterised by high Mg content ranging from 4330 to 5990 ppm, low Mn content from below detection limit (d.I.) to 120 ppm, low Fe content from 216 to $830 \mathrm{ppm}$, and low Sr content from 221 to $440 \mathrm{ppm}$ (see complete dataset in appendices I and II). The stable isotope composition of the Jbel Choucht Fm. yielded $\delta^{13} \mathrm{C}$ values ranging from +0.19 to $+1.57 \%$ ovPDB and $\delta^{18} \mathrm{O}$ values ranging from -3.62 to -2.76 \%ovPDB (Fig. 8; see complete dataset in appendices I and II). The Aganane Fm. carbonates (C3) are characterised by $\mathrm{Mg}$ content ranging from 4500 to $5275 \mathrm{ppm}$, Mn content always below the d.I., Fe content from below the d.I. to $1750 \mathrm{ppm}$, and $\mathrm{Sr}$ content from 
336

337

338

339

340

341

342

343

344

345

346

347

348

349

350

351

352

353

354

355

356

357

358

359

360

361

362

363

364

365

150 to $495 \mathrm{ppm}$. The stable isotope analysis yielded $\delta^{13} \mathrm{C}$ values ranging from -1.71 to $+1.93 \%$ ovPDB and $\delta^{18} \mathrm{O}$ ranging from -8.20 to $-3.47 \%$ ovPDB.

Although the elemental composition of the karstic sediments CS1, CS2 and CS3 is not available due to sampling difficulties, stable isotope data shows that CS1 significantly defers from CS2 and CS3 (Fig. 8). CS1 is characterised by $\delta^{13} \mathrm{C}$ values ranging from -2.79 to $-3.06 \%$ oVPDB, and $\delta^{18} \mathrm{O}$ values ranging from -4.18 to $-3.90 \%$ ovPDB, while CS2 and CS3 show $\delta^{13} \mathrm{C}$ values varying from -6.98 to $-5.68 \%$ оvPDB and $\delta^{18} \mathrm{O}$ values varying from -7.81 to $-6.15 \%$ ovPDB (Fig.8).

Calcite cement CC1, filling inter-particle porosity in the Jbel Choucht Fm., is characterised by high $\mathrm{Mg}$ content ranging from 3600 to 5465 ppm, Mn content from below d.I. to $242 \mathrm{ppm}$, Fe content from below d.I. to 708 ppm, and Sr content from below d.I. to 435 ppm (Fig. 9). Calcite cement 2 (CC2) from the Aganane Fm. shows $\delta^{13} \mathrm{C}$ values ranging from +2.22 to $+2.33 \%$ оVPDB and $\delta^{18} \mathrm{O}$ values ranging from -6.90 to -6.26 \%ovPDB (Fig. 8A). CC1 isotope analysis and CC2 elemental analysis are not available due to sampling difficulties associated with the small crystal size. CC3 calcite cement is characterised by $\mathrm{Mg}$ content ranging between 1740 and 8555 ppm, Mn content from below d.I. to 2200, Fe content from below d.I. to 2170, and Sr content below d.I. to 523 ppm. CC3 yielded $\delta^{13} \mathrm{C}$ values ranging from +0.73 to $+1.75 \%$ ovPDB and $\delta^{18} \mathrm{O}$ ranging from -8.61 to $-7.54 \%$ ovPDB.

Calcite cement CC4 analysed in the Aït Bou Oulli Fm. slivers (CC4-S) is characterised by Mg content ranging from below d.I to 1500 ppm, Mn content from 426 to 1636 ppm, Fe content from below the d.I. to 880 ppm, and Sr content from below d.I. to 294 ppm. CC4-S isotope analysis yielded a $\delta^{13} \mathrm{C}$ value of $+1.10 \%$ оvPDB and a $\delta^{18} \mathrm{O}$ value of -5.57 \%ovPDB. Calcite cement CC4-F analysed in the units flanking the diapiric structure differs from CC4-S in elemental composition. Mg content ranges from 542 to 10394 ppm, Mn content from below the d.I. to 393 ppm (much lower than CC4-S), Fe content from below d.I. to $3707 \mathrm{ppm}$ (higher than CC4-S), and Sr content from below d.I. to $2838 \mathrm{ppm}$ (higher than CC4-S, Fig. 9). In contrast, the isotopic composition of CC4-F is similar to CC4-S, with values ranging from $\delta^{13} \mathrm{C}$ values ranging from -0.33 to $+1.91 \%$ ovPDB and $\delta^{18} \mathrm{O}$ values ranging from -6.50 to $-4.12 \%$ ovPDB (Fig. $8 \mathrm{~B}$ ). 
Calcite cement 5 (CC5) is very similar to CC4-F in elemental geochemistry, with $\mathrm{Mg}$ content ranging from 611 to 7567 ppm, Mn content from below the d.I. to 1160 ppm, Fe content from below d.I. to 4524 ppm, and Sr content from 154 to 1945 ppm. In contrast, CC5 clearly differs from CC4-F in the isotopy composition, with $\delta^{13} \mathrm{C}$ values ranging from -3.38 to $+0.51 \%$ oVPDB and $\delta^{18} \mathrm{O}$ values ranging from -16.80 to $-8.87 \%$ oVPDB

371 (Fig. 8B).

372 CC6 shows Mg content ranging from below d.I. to $2900 \mathrm{ppm}, \mathrm{Mn}$ content from below 373 d.I. to 2644 ppm, Fe content from below d.I. to 3806 ppm, and Sr content from below 374 d.I. and 328ppm. CC6 isotopy yielded $\delta^{13} \mathrm{C}$ values ranging from -4.30 and $-3.08 \%$ ovPDB, 375 and $\delta^{18} \mathrm{O}$ ranging from -6.75 to $-5.78 \%$ оvPDB. CC7 is characterised by $\mathrm{Mg}$ content ranging from 2000 to 3500 ppm, Mn content from below the d.I. up to 17832 ppm, Fe content from below the d.I. to $356 \mathrm{ppm}$, and Sr content from below the d.I. to $348 \mathrm{ppm}$. CC7 isotopic composition shows $\delta^{13} \mathrm{C}$ ranging from -8.46 to $-6.22 \%$ ovPDB and $\delta^{18} \mathrm{O}$ ranging from -8.41 to $-6.33 \%$ ovPDB (Fig. 8B).

Replacive dolomite 1 (RD1) is characterised by high Mg content ranging from 11.79 to 13.17\%, low Mn content from 488 to 2155 ppm, and low Fe content from below d.I. to 9650 ppm. RD1 isotope analysis shows $\delta^{13} \mathrm{C}$ values ranging from +1.71 to $+2.70 \%$ ovPDB, and $\delta^{18} \mathrm{O}$ values ranging from -4.74 to $-1.76 \%$ ovPDB (Fig. $8 \mathrm{~A}$ and dataset in appendices I and II). The Pliensbachian Aganane Fm. replacive dolomite 1 (RD2) is characterised by high Fe content varying from 6.5 to 10.8 \%, low Mn content from 760 to 1475 ppm, low Mg content from 5.6 to 7.4 \%, and Sr content below 375 ppm (Fig. 9). RD2 isotope analysis yielded a $\delta^{13} \mathrm{C}$ value of $-0.69 \%$ ovPDB and a $\delta^{18} \mathrm{O}$ value of $-3.12 \%$ ovPDB.

Replacive dolomite 3 (RD3) shows $\delta^{13} \mathrm{C}$ ranging from -2.27 to $-0.3 \%$ ovPDB and $\delta^{18} \mathrm{O}$ ranging from -7.24 to $-5.13 \%$ ovPDB. Saddle dolomite 1 (SD1) is characterised by $\delta^{13} \mathrm{C}$ ranging from -3.56 to $-1.79 \%$ oVPDB, and $\delta^{18} \mathrm{O}$ ranging from -7.45 to $-5.19 \%$ ovPDB (Fig. 7B). 391 The elemental analysis of both RD3 and SD1 dolomites are similar (data in supplementary material). They are characterised by $\mathrm{Mg}$ content ranging from 91396 to 112635 ppm, Mn content from 290 to 1981 ppm, Fe content from 3473 to 54640 ppm, and Sr content from 187 to 2416 ppm. 
395 Calcitized dolomite 1 (CD1) is characterised by highly variable $\mathrm{Mg}$, Fe and Sr contents, ranging from 700 to $10400 \mathrm{ppm}$, from below the d.I. to 4918 and from below the d.I. to 3089 ppm, respectively, and by a very low Mn content from below d.I. to 310 ppm. CD1 yielded $\delta^{13} \mathrm{C}$ values ranging from -7.24 to $-3.25 \%$ ovPDB and $\delta^{18} \mathrm{O}$ values that range from 6.43 to $-6.00 \%$ ovPDB.

400

\section{DISCUSSION}

401

402

403

404

405

406

407

408

409

410

411

412

413

414

415

416

417

418

419

420

421

422

Stage 1. Marine diagenesis (early Pliensbachian)

The first stage is characterised by the deposition of the Pliensbachian platform carbonates of the Jbel Choucht Fm. (C2), and thus is dominated by marine pore fluids (Fig. 8, 9 and 10). Such fluids facilitated the precipitation of the calcite cement CC1 that occluded the inter-particle porosity of the host limestones. After the precipitation of CC1, the Hettangian-Lower Sinemurian Aït bou Oulli Fm. slivers and the lowermost part of the Jbel Choucht Fm. were partially replaced by RD1 (Fig. 3 and 4). The distribution of RD1 in Jbel Choucht Fm., which decreases upwards and away from the diapir, suggests that dolomitizing fluid most likely migrated along the diapir margin. Based on field and analytical data, two main hypotheses are envisaged for the origin of RD1. The dolomitizing fluids could be related to the downward percolation of seawater derived fluids along fractures (e.g. Fischer et al., 2013). In this regard, fracturing and faulting of the sedimentary overburden above salt diapirs are typically associated with reactive and active stages of diapirism (Davison et al., 2000; Jackson et al., 1994; Vendeville et al., 1992). Taking into account that during early Pliensbachian times the Tazoult salt wall was in a stage of reactive-active growth linked to the Early Jurassic rifting of the central High Atlas (Martín-Martín et al., 2017; Moragas et al., 2018; Saura et al., 2014; Vergés et al., 2017), it is suggested that the fracturing of the Jbel Choucht Fm. at that time likely provided conduits for the downward circulation of marine fluids until the crest of the diapir (Fig. 10). The similar $\delta^{13} \mathrm{C}$ (from +1.71 to $+2.7 \%$ ovPDB) and slightly depleted $\delta^{18} \mathrm{O}$ values (from -4.74 to $-1.76 \%$ ovPDB) of RD1 compared to Early Jurassic seawater points to warm marine water as dolomitizing fluid (Fig. 8). The increase in temperature of 
seawater at shallow depths is attributed to the occurrence of high geothermal gradient associated with the rifting stage (Moragas et al., 2018).

425 Alternatively, the origin of RD1 could be associated with the upwards flow of dolomitising fluids by using the diapir margin as a major pathway (e.g., Enos et al., 2002;

427 Masoumi et al., 2014). In this scenario, the upwards migration of fluids would be driven by burial compaction of the Sinemurian and Pliensbachian marly deposits that underlie the Jbel Choucht Fm. out of the diapir and basinwards, subsequently the fluids focused along the diapir margin. An upwards circulation of Sinemurian or Pliensbachian marinederived fluids warmed at depth is supported by the slightly depleted $\delta^{18} \mathrm{O}$ and positive $\delta^{13} \mathrm{C}$ values of RD1. Furthermore, the limited volume of dolomitized rock is in agreement with a compaction driven mechanism as dolomitizing fluids expelled by burial compaction commonly result in limited amount of replacive dolomite (Machel, 2004; Warren, 2000).

437 After the deposition of the Jbel Choucht Fm., the Tazoult salt wall underwent an increased diapiric growth with respect to early Pliensbachian times (Martín-Martín et al., 2017). According to Martín-Martín et al. (2017), the growth of the salt wall promoted the uplift and subaerial exposure of the Jbel Choucht carbonate platform, resulting in the invasion of the platform top by meteoric waters and the karstification of the host limestones (Fig. 10). Accordingly, the depleted $\delta^{13} \mathrm{C}$ values (from -6.98 to $-2.79 \%$ ovPDB) yielded by the karstic sediments CS1 and CS2 are consistent with a meteoric alteration

444 (Fig. 7, 9 and 10). Following the meteoric alteration, the continuous growth of the 445 Tazoult salt wall caused the erosion of the karst and the deposition of down-flank syndiapiric sedimentary breccias, conglomerates and sandstones of the Talmest-n'Tazoult Fm. The presence of Triassic clasts in the breccia indicates that the diapir core rocks were cropping out at that time (Fig. 4D). These clastic deposits pass laterally and towards the top to marly facies, and finally to the Aganane platform carbonates, representing a transition to marine-dominated environment that characterised stage 3. diapiric structures and the rapid change in facies distribution around them and 
basinwards have been previously reported in the Tazoult salt wall (Joussiaume, 2016; Malaval, 2016; Martín-Martín et al., 2017; Vergés et al., 2017), as well as in other diapiric structures of the central High Atlas (Teixell et al., 2017) and in diapiric basins elsewhere 456 (Counts et al., 2019; Giles et al., 2008; Poprawski et al., 2016). However, the karstification of platform carbonates forming the crest of these diapirs and their subsequent erosion and sedimentation as clastic deposists around them has rarely been reported in the literature, and thus constitutes a key diference of the Tazoult salt wall with other case studies.

Stage 3 and 4. Marine to meteoric diagenesis (late Pliensbachian)

462

The stages 3 and 4 occurred in a transitional environment with interaction between marine and meteoric fluids as recorded by: i) the deposition of the Pliensbachian Aganane Fm. limestones (C3) in a lagoon environment (Bouchouata et al., 1995; Fraser et al., 2004; Lee, 1983), and the presence of small-scale karstic cavities (pockets and fissures) at top of the Aganane carbonate platform that are filled with sediments showing a meteoric isotopic signature (CS3 in Fig. 8 and 9). The Aganane limestones (C3) show lower $\delta^{18} \mathrm{O}$ values than the values expected for the Pliensbachian marine carbonates (Della Porta et al., 2015; Veizer et al., 1999) indicating that they were later overprinted by modified-marine fluids during progressive burial of the rock (Moore, 2001). In this setting, the Aganane Fm. limestones were locally replaced by RD2. Despite the limited analytical data of RD2, the slightly depleted $\delta^{13} \mathrm{C}$ and $\delta^{18} \mathrm{O}$ values $(-0.69$ and $-3.12 \%$ ovpdB respectively) together with the high iron content and the dull (nonluminescent) colour under cathodoluminescence suggests a dolomitization from marine-derived fluids in chemically reducing conditions (Boggs, 2003; Machel et al., 1991). Such reducing conditions are typically related to burial environments (Banner et al., 1990; Machel, 2004), implying that the replacement by RD2 likely occurred at the end of the 4 or even during the early phases of stage 5 (shallow burial).

Stage 5. Shallow burial diagenesis (Toarcian)

The increase in sedimentation rate and siliciclastic input during Toarcian times caused a rapid burial of the Pliensbachian platform carbonates together with the increase in the rate of the Tazoult salt wall rise associated with salt withdrawal from the adjacent 
483

484

485

486

487

488

489

490

491

492

493

494

495

496

497

498

499

500

501

502

503

504

505

506

507

508

509

510

511

512

513

minibasin (Martín-Martín et al., 2017). This change of salt-induced dynamics marks the onset of burial diagenesis (Fig. 10), which is interpreted to result in the precipitation of calcite cement CC3 in the inter-particle and vug porosity of the Pliensbachian platform carbonates flanking the Tazoult salt wall (Jbel Choucht, Talmest-Tazoult and Aganane formations). Crosscutting relationships indicate that CC3 cementation was followed by the replacement of the karstic sediments CS1 and CS3 to form RD3, and the precipitation of SD1 in fractures (Fig. 10).

The similar carbon and oxygen isotopic signature of RD3 and SD1 suggests formation from a fluid with similar geochemical characteristics (Fig. 8). On the one hand, the negative $\delta^{13} \mathrm{C}$ values (from -3.56 to $-0.43 \%$ ovPDB ) likely reflect an input of light carbon from thermally decarboxylized organic matter (Moore et al., 2013; Spötl et al., 1998). On the other hand, the relatively depleted $\delta^{18} \mathrm{O}$ values (from -7.45 to $-5.13 \%$ ovpDB) suggests formation from relatively high temperature fluids (Allan et al., 1993; Spötl et al., 1998). In this regard, saddle dolomite is considered to precipitate from hot basinal, frequently hydrothermal, fluids (Davies et al., 2006; Mansurbeg et al., 2016; Morad et al., 2018), with temperatures above 60ㄷ (Spötl et al., 1998). Therefore, the most probable scenario is that RD3 and SD1 formed from light carbon and high temperature Mg-rich fluids expelled from the Zawyat Ahançal Group sediments or the Pliensbachian basinal marls, which are in lateral contact with the Pliensbachian platform carbonates, using faults, fractures and the margin of the Tazoult salt wall as major conduits (Fig. 10).

According to crosscut relationships, the formation of RD3 and SD1 dolomites was followed by the precipitation of the calcite cement CC4-F. The calcite cement CC4-S, with similar isotopic signature and petrological characteristics, precipitate in the Aït bou Oulli Fm. slivers. According to the isotopic signature, we interpret both calcite cement CC4-F and CC4-S to precipitate in a similar diagenetic environment (shallow burial), but from two different fluids as CC4-S shows higher Mn content (426 to $1636 \mathrm{ppm}$ ) than the equivalent cement CC4-F (below d.I. to 393 ppm) (Fig. 9). The lack of RD3 and SD1 in the Ait bou Oulli Fm. slivers compared to the flanks of the Tazoult salt wall, and the differences in origin between calcite cements CC4-F and $-S$, suggest that the exchange of fluids between the flanks and the core of the diapir was very limited during this stage (Fig. 10). 
515 The continuation of sediment supply and the progressive increase in burial depth during 516 Middle Jurassic characterised the diagenetic evolution of the Pliensbachian carbonate 517 platforms after the Toarcian (Martín-Martín et al., 2017). During this stage calcite 518 cements precipitated in the remaining porosity as: (i) CC5 in Pliensbachian carbonates and breccias, and (ii) CC6 in the Hettangian-Lower Sinemurian Aït bou Oulli slivers (Fig. 10). This differentiated cementation suggests that the Tazoult salt wall acted as a physical barrier for the migration of fluids between the core and the flanking sediments as previously reported from other diapir structures like those of La Popa Basin (e.g. Smith et al., 2012).

524 The highly depleted $\delta^{18} \mathrm{O}$ values of calcite cement CC5 (from -16.80 to $-8.87 \%$ ovPDB) suggest that the flanking carbonates were most probably affected by hot basinal brines. Crosscutting relationships indicate that CC5 pre-dates the stage of exhumation and uplift (Stage 7), and thus is the last cement that precipitated during deep burial diagenesis. According to burial and thermal models by Moragas et al., (2018), the maximum burial of the Pliensbachian sediments in the minibasins flanking the Tazoult salt wall occurred from Middle Jurassic to Early Cretaceous times, reaching temperatures between 150 and $250 \circ \mathrm{C}$. The units flanking the diapir, however, are not expected to reach these temperatures as (i) they were affected by less burial than the equivalent units located in the minibasin centre, and (ii) the high thermal conductivity of salt causes negative thermal anomalies in the vicinity of diapiric structures (Li et al., 2017; Magri et al., 2008; Petersen et al., 1995, 1996). Thus, the formation of CC5 would be probably associated with abnormal and relatively high temperature fluids, likely hydrothermal, documented in the area during Middle to Late Jurassic. This high temperature would be related to: (i) the emplacement of gabbros in the core of the Tazoult salt wall (see Martín-Martín et al., 2017), and/or (ii) the emplacement of veinlike Mississippi Valley-type ore deposit hosted in the Pliensbachian Jbel Choucht carbonates of the Tazoult south flank (Pb-Zn ore deposits from the Aguerd n'Tazoult mine according to Mouttaqi et al., 2011). Field observations indicate that the ore deposit post-date the magmatic intrusions, and thus the MVT deposit of Tazoult most probably formed after Middle Jurassic times. $\mathrm{Zn}-\mathrm{Pb}$ ore deposits hosted in Middle Jurassic 
545 carbonates flanking salt structures equally intruded by gabbros have been recently 546 reported in other localities of the central High Atlas. In the Ikkou Ou Ali salt wall (central 547 High Atlas of Imilchil), $\mathrm{Zn}-\mathrm{Pb}$ ore deposits have been determined to form between Late 548 Middle Jurassic and Early Cretaceous under an extensional regime (Mouttaqi et al., 549 2011; Rddad et al., 2018). According to these authors, the origin of the Ikkou Ou Ali ore 550 deposit is related to the mixing of a basement-derived hot and metal-bearing fluids that 551 migrated upwards through faults with a sulphur-rich fluid derived from the dissolution 552 of Triassic evaporites. Maximum temperatures reported from Ikkou Ou Ali Zn-Pb deposit 553 and related calcite cements are up to $206^{\circ} \mathrm{C}$ (Rddad et al., 2018).

554 In contrast to the diapir flanks, the Aït bou Oulli Fm. slivers were cemented by the calcite 555 cement CC6. Similarly to CC4-S, calcite cement CC6 shows a high Mn content (up to 2644 $556 \mathrm{ppm}$ ), which is a key difference with other diagenetic phases described here (Fig. 9).

557 The origin of a Mn-rich fluid exclusively affecting the carbonate slivers embedded in the

558 Tazoult core rocks could be associated with: (i) Triassic clayely sediments of the salt wall 559 (Chukhrov et al., 1980), and (ii) hydrothermal fluids associated with the intrusion of 560 gabbro in the core of the salt wall, as magma partitioning can result in fluids rich in base 561 metals such as Mn (Schindler et al., 2016; Sharma et al., 2016) (Fig. 10). Similarly, the 562 fluorite cement that exclusively appears in the Aït bou Oulli Fm. slivers would be 563 associated with intra-core fluids. The fluorite likely precipitated from high saline fluids 564 related to the leaching of evaporites from the core of the Tazoult salt wall (Pique et al., 565 2008; Sánchez et al., 2009). Calcite cement CC6 appears cementing the breccias in the 566 Aït bou Oulli Fm. slivers, which is composed of a variety of clasts including host rock (RD1 567 and D1) and several generations of cements precipitated at different times during the 568 diapiric evolution (CC4-S and Fluorite). This highlights that fracturing and brecciation are 569 recurrent processes not only in the sediments flanking the diapiric structure but also in 570 the slivers embedded in the core. This observation is in agreement with numerical 571 simulations results fromLi et al. (2012), demonstrating that fragmentation and 572 brecciation of intra-salt carbonate blocks in Oman was continuous all along the 573 evolution of the diapiric structures.

574 Stage 7. Meteoric diagenesis (Cenozoic) 
575 The uplift of the Tazoult salt wall during the Alpine inversion promoted the exposure 576 and erosion of the diapiric core rocks and the flanking sediments, facilitating the 577 circulation of meteoric waters (Fig. 8, 9 and 10). Accordingly, this stage is characterised

578 by the late karstification of the Hettangian-lower Sinemurian Aït bou Oulli slivers and 579 the Pliensbachian Jbel Choucht and Aganane carbonate platforms. The interaction 580 between the latter units and meteoric fluids likely caused the calcitization of dolomites 581 resulting in the calcitized dolomite CD1 and the precipitation of the calcite cement CC7. 582 The succession of non-luminescent to orange bright rimmed luminescent cement (CC7) 583 could be interpreted as meteoric or shallow burial in origin (Carpenter et al., 1989; 584 Meyers, 1974; Moldovany et al., 1984). However, the meteoric origin of this cement is 585 further supported by the stable carbon and oxygen isotope results, ranging from -8.46 586 to $-6.22 \%$ ovPDB for $\delta^{13} \mathrm{C}$ and from -8.41 to $-6.33 \%$ ovPDB for $\delta^{18} \mathrm{O}$ (Lonhmann, 1988; Moore, 587 2001).

588

\section{$5897 . \quad$ CONCLUSIONS}

590 This study presents the diagenetic evolution of Hettangian to Pliensbachian platform carbonates that fringe the Tazoult salt wall located in the central High Atlas diapiricbasin

592 (Morocco). Specifically, the study investigates the diagenetic alterations that affect (i)

593 Hettangian-Lower Sinemurian carbonates distributed as slivers within the core of the 594 diapir, and ii) Pliensbachian Jbel Choucht and Aganane formations that appear flanking the salt wall. Moreover, the latter platforms are separated by an important karstic surface and the Talmest-n'Tazoult Fm., representing a major characteristic of the studied area compared to other case studies worldwide.

598 Using field and analytical data, we were able todraw the entire diagenetic evolution 599 occurred in a diapir since the early stages of the diapiric activity up to their inversion.

600 We recognise the following seven diagenetic stages that are linked to the halokinetic 601 evolution of the Tazoult salt wall: 
602 Stage 1 (early Pliensbachian) to stage 4 (late Pliensbachian) occurred during the early 603 growth of the Tazoult salt wall and are dominated by an alternation of marine and 604 meteoric diagenetic environments. The former diagenetic processes are characterised 605 by the circulation of dolomitizing fluids along the diapir margin that resulted in the 606 interaction with the bottom part of the host carbonates. Likewise, the continuous 607 growth of the diapir caused the exposure and karstification of the carbonate platforms 608 through interaction with meteoric fluids.

609 Stage 5 (Toarcian) and stage 6 (post-Toarcian) represent the burial of the studied 610 carbonates and breccias and are characterised by the Tazoult salt wall acting as a barrier 611 to fluid exchangethe flanking units and the core of the structure. The Pliensbachian 612 platform carbonates and breccias located in the flanks of the diapir were affected by the 613 circulation of hot basinal brines, which result in the precipitation of dolomite and calcite 614 cements in fracture-related porosity. Contrarily, the slivers of Hettangian carbonates 615 embedded within the core of the structure interacted with Mn-rich fluids derived from 616 the clayey Triassic rocks and/or hydrothermal fluids associated with the intrusion of 617 gabbros.

618 Stage 7 (Cenozoic) corresponds to the uplift and exhumation event related to the Alpine 619 compression. During this stage, the Hettangian to Pliensbachian carbonates and breccias 620 were exposed and interacted with meteoric waters, which result in the calcitization of dolomites and the precipitation of calcite cement.

622 The study of the Tazoult salt wall highlights how the diapiric activity influcences the 623 diagenetic evolution of the fringing platform carbonates by: i) creating fluid pathways 624 (fractures) due to the forces caused by the growth of the salt structures; ii) local relative 625 water depth variation due to vertical salt movement that causes alternance of marine 626 and meteoric diagenetic processes, and the exposure and karstification of the 627 carbonates, iii) diapirs and welds which act as as preferencial vertical conduits but as 628 barriers for horizontal migration of fluids, and iv) salt and other evaporites dissolution 629 that influences the chemistry of the fluids. 
631

632

633

634

635

636

637

638

639

640

641

642

643

644

645

646

647

648

649

650

651

652

653

654

655

656

657

658

659

660

661

662

663

664

665

666

667

668

669

670

671

672

673

674

675

676

677

678

679

680

681

682

683

Allan, J. R., \& Wiggins, W. D. (1993). Dolomite reservoirs. Geochemical techniques for evaluating origin and distribution. In AAPG (Ed.), Continuing Education Course Notes Series (Vol. 36, pp. 129).

Arboleya, M. L., Teixell, A., Charroud, M., \& Julivert, M. (2004). A structural transect through the High and Middle Atlas of Morocco. Journal of African Earth Sciences, 39(3-5), 319-327. Retrieved from http://www.scopus.com/inward/record.url?eid=2-s2.08644240184\&partnerID $=40 \&$ md $5=69 f 703701785 \mathrm{e} 28 \mathrm{c} 662 \mathrm{ff} 8 \mathrm{~b} 7 \mathrm{~b} 4918 \mathrm{f} 48$

Banner, J. L., \& Hanson, G. N. (1990). Calculation of simultaneous isotopic and trace element variations during water-rock interaction with applications to carbonate diagenesis. Geochimica et Cosmochimica Acta, 54, 3123-3137.

Beauchamp, W., Allmendinger, R. W., Barazangi, M., Demnati, A., El Alji, M., \& Dahmani, M. (1999). Inversion tectonics and the evolution of the High Atlas Mountains, Morocco, based on a geological-geophysical transect. Tectonics, 18(2), 163-184. Retrieved from http://www.scopus.com/inward/record.url?eid=2-s2.0-

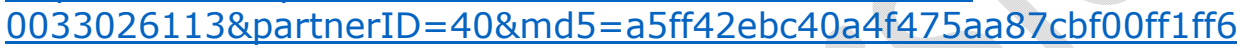

Beavington-Penney, S. J., Nadin, P., Wright, V. P., Clarke, E., McQuilken, J., \& Bailey, H. W. (2008). Reservoir quality variation on an Eocene carbonate ramp, El Garia Formation, offshore Tunisia: Structural control of burial corrosion and dolomitisation. Sedimentary Geology, 209(1-4), 42-57. Retrieved from http://www.scopus.com/inward/record.url?eid=2-s2.0-

50349095459\&partnerID =40\&md5=9d998ca64410fd47f13bb5700e3ba87b

Boggs, S. (2003). Petrology of Sedimentary Rocks (1st Edition ed.): Blackburn Press.

Bosence, D. (2005). A genetic classification of carbonate platforms based on their basinal and tectonic settings in the Cenozoic. Sedimentary Geology, 175(1-4 SPEC. ISS.), 49-72. Retrieved from http://www.scopus.com/inward/record.url?eid=2-s2.016844380220\&partnerID =40\&md5=44f23a52fd16a984da35839a0d80c732

Bouchouata, A. (1994). La ride de Talmest-Tazoult (Haut Atlas Central Maroc), lithostratigraphie, biostratigraphie et relations tectonique-sédimentation au cours du Jurassique. Strata, série 2 (memoires), 25(8), 219. Retrieved from http://www.scopus.com/inward/record.url?eid=2-s2.00028862654\&partnerID =40\&md5=e0941f60a7db7559627ac603e77b9099

Bouchouata, A., Canerot, J., Souhel, A., \& Almeras, Y. (1995). Jurassic sequence stratigraphy and geodynamic evolution in the Talmest-Tazoult area, Central High Atlas, Morocco. Comptes Rendus de I'Académie des Sciences, 320(8), 749-756. Retrieved from http://www.scopus.com/inward/record.url?eid=2s2.00028862654\&partnerID $=40 \&$ md5=e0941f60a7db7559627ac603e77b9099

Carpenter, S. J., \& Lonhmann, K. C. (1989). D180 and d13C variations in late Devonian marine cements from the Golden Spike and Nevis reefs, Alberta, Canada. J ournal of Sedimentary Petrology, 59, 792-814.

Claypool, G. E., Holser, W. T., Kaplan, I. R., Sakai, H., \& Zak, I. (1980). The age curves of sulfur and oxygen isotopes in marine sulfate and their mutual interpretation. Chemical Geology, 28(C), 199-260. Retrieved from http://www.scopus.com/inward/record.url?eid=2-s2.049149142127\&partnerID =40\&md5=95ae30d83706eb9acbb68a091997f338

Chukhrov, F. V., Gorshkov, A. J., Rudnitskaya, E. D., Beresovskaya, V. V., \& Sivtsov, A. V. (1980). Manganese minerals in clays: a review. Clays and Clay Minerals, 28(5), 346-354. 
Counts, J. W., Dalgarno, C. R., Amos, K. J., \& Hasiotis, S. (2019). Lateral facies variability along the margin of an outcropping salt-withdrawal minibasin, South Australia. J ournal of Sedimentary Research, 89, 28-45. Davies, G. R., \& Smith Jr, L. B. (2006). Structurally controlled hydrothermal dolomite reservoir facies: An overview. AAPG Bulletin, 90(11), 1641-1690.

Davison, I., Alsop, G. I., Evans, N. G., \& Safaricz, M. (2000). Overburden deformation patterns and mechanisms of salt diapir penetration in the Central Graben, North Sea. Marine and Petroleum Geology, 17(5), 601-618. Retrieved from http://www.scopus.com/inward/record.url?eid=2-s2.0-Della Porta, G., Webb, G. E., \& McDonald, I. (2015). REE patterns of microbial carbonate and cements from Sinemurian (Lower Jurassic) siliceous sponge mounds (Djebel Bou Dahar, High Atlas, Morocco). Chemical Geology, 400, 65-86. doi:https://doi.org/10.1016/j.chemgeo.2015.02.010

Dickson, J. A. D. (1966). Carbonate Identification and Genesis as Revealed by Staining. J ournal of Sedimentary Research, 36(2), 491-505.

Enos, J. S., \& Kyle, J. R. (2002). Diagenesis of the Carrizo sandstone at Butler salt dome, East Texas Basin, U.S.A.: Evidences for fluid-sediment interaction near halokinetic structures. Journal of Sedimentary Research, 72(1), 68-81. doi:http://dx.doi.org/10.1306/061101720068

Ettaki, M., Ibouh, H., Chellaï, E. H., \& Milhi, A. (2007). Liassic diapiric structures from the Central High Atlas, Morocco; Ikerzi ride example. Africa Geoscience Review, 14(1-2), 79-93. Retrieved from http://www.scopus.com/inward/record.url?eid=2-s2.040549100390\&partnerID =40\&md5=d4f6bbc4956b9b1f7f2f007d07522fcb

Fischer, M. P., Kenroy, P. R., \& Smith , A. P. (2013). Fluid systems around salt diapirs. AAPG Search and Discovery, \#50902, 1-29.

Fraser, N. M., Bottjer, D. J., \& Fischer, A. G. (2004). Dissecting "Lihiotis bivalves: Implications for the Early Jurassic reef eclipse. Palaios, 19, 51-67.

Frizon de Lamotte, D., Bezar, B. S., Bracène, R., \& Mercier, E. (2000). The two main steps of the Atlas building and geodynamics of the western Mediterranean. Tectonics, 19(4), 740-761.

Frizon de Lamotte, D., Zizi, M., Missenard, Y., Hafid, M., Azzouzi, M., Maury, R. C., Charrière, A., Taki, Z., Benammi, M., \& Michard, A. (2008). The Atlas System. In Continental Evolution: The Geology of Morocco (pp. 133-202).

Ghazban, F., \& Al-Aasm, I. S. (2010). Hydrocarbon-induced diagenetic dolomite and pyrite formation associated with the hormoz island salt dome, offshore iran. Journal of Petroleum Geology, 33(2), 183-196. Retrieved from http://www.scopus.com/inward/record.url?eid=2-s2.077954407367\&partnerID =40\&md5=a89ac205a3f8f60f9bbd8b0d88cef3ba

Giles, K. A., Druke, D. C., Mercer, D. W., \& Hunnicutt-Mack, L. (2008). Controls on Upper Cretaceous (Maastrichtian) heterozoan carbonate platforms developed on Salt diapirs, La Popa Basin, NE Mexico. SEPM Special Publication, 89.

Hailwood, E. A., \& Mitchell, J. G. (1971). Palaeomagnetic and Radiometric Dating Results from Jurassic Intrusions in South Morocco. Geophysical Journal International, 24(4), 351-364. doi:10.1111/j.1365-246X.1971.tb02183.x

Ibouh, H., El Bchari, F., Bouabdelli, M., Souhel, A., \& Youbi, N. (2001). L'accident Tizal-Azourki haut atlas central du maroc: Déformations synsŕdimentaires liasiques en extension et conséquences du serrage atlasique. Estudios Geológicos, 57(1-2), 15-30. Retrieved from http://www.scopus.com/inward/record.url?eid=2-s2.077955194456\&partnerID $=40 \&$ md5 $=614 c 2 d 1 a 5 a 33 c a 3 b 50650 d 2 c 4 a 5076 c 3$

Jackson, M. P. A., Vendeville, B. C., \& Shultz-Ela, D. D. (1994). Structural dynamics of salt systems. Annual Review of Earth and Planetary Sciences, 22, 93-117. Retrieved from http://www.scopus.com/inward/record.url?eid=2-s2.00028571329\&partnerI $\mathrm{D}=40$ \&md5=8644cc3f8b06a7864bdecd964262e345 
Jossen, J. A., \& Couvreur, G. (Cartographer). (1990). Carte Géologique du Marroc, feuille Zawyat Ahançal

Joussiaume, R. (2016). "Les relations entre diapirisme et sédimentation: Exemple du Jurassique moyen de la région d'Imilchil, Haut-Atlas central, Maroc". (The relationships between diapirism and sedimentation: An example from the Middle Jurassic of the Imilchil area, Central High-Atlas, Morocco.). (PhD), Université Bordeaux-Montaigne Pessac, France.

Laville, E., \& Harmand, C. (1982). Magmatic and tectonic evolution of Mesozoic intracontinental basin High- Atlas Mountains, Morocco: a model of synsedimentary anorogenic intrusions linked to strike slip faults. Bulletin de la Société Géologique de France, 24(2), 213-227. Retrieved from http://www.scopus.com/inward/record.url?eid=2-s2.00020387037\&partnerID $=40 \&$ md5 $=73$ d1ca314ec9f479a5b80a4af5bee2bd

Laville, E., Lesage, J.-L., \& Seguret, M. (1977). Geometrie, cinematique (dynamique) de la tectonique atlasique sur le versant sud du Haut Atlas marocain; apercu sur les tectoniques hercyniennes et tardi-hercyniennes. Bulletin de la Société Géologique de France, Series 7 Vol. XIX(3), 527-539. doi: $10.2113 /$ gssgfbull.S7-XIX.3.527

Laville, E., \& Piqué, A. (1992). Jurassic penetrative deformation and Cenozoic uplift in the Central High Atlas (Morocco): A tectonic model. structural and orogenic inversions. Geologische Rundschau, 81(1), 157-170. Retrieved from http://www.scopus.com/inward/record.url?eid=2-s2.00026459438\&partnerID =40\&md5=e1e0115b2dbc1c13abaa21771bca6731

Lee, C. W. (1983). Bivalve mounds and reefs of the central High Atlas, Morocco. Palaeogeography, Palaeoclimatology, Palaeoecology, 43, 153-168.

Li, S., Abe, S., Reuning, L., Becker, S., Urai, J. L., \& Kukla, P. A. (2012). Numerical modelling of the displacement and deformation of embedded rock bodies during salt tectonics: A case study from the South Oman Salt Basin. Geological Society, London, Special Publications, 363(1), 503-520. doi: $10.1144 / \mathrm{sp} 363.24$

Li, S., Reuning, L., Marquart, G., Wang, Y., \& Zhao, P. (2017). Numerical model of halite precipitation in porous sedimentary rocks adjacent to salt diapirs. J ournal of Geophysics and Engineering, 14, 1160-1166.

Lonhmann, K. C. (1988). Geochemical patterns of meteoric diagenetic systems and their application to studies of paleokarst. In N. P. James \& P. W. Choquette (Eds.), Paleokarst (pp. 58-80). New York: Springer.

Machel, H. G. (2004). Concepts and models of dolomitization: a critical reappraisañl. Geological Society, London, Special Publications, 235(1), 7-63.

Machel, H. G., \& Burton, E. A. (1991). Factors governing cathodoluminescence in calcite and dolomite, and their implications for studies of carbonate diagenesis. . In C. E. Baker \& O. C. Kopp (Eds.), Luminescence microscopy and spectroscopy: qualitative and quantitative applications (Vol. 25, pp. 1-7).

Magri, F., Littke, R., Rodon, S., Bayer, U., \& Urai, J. L. (2008). Temperature fields, petroleum maturation and fluid flow in the vicinity of salt domes. In R. Littke, U. Bayer, D. Gajewski, \& S. Nelskamp (Eds.), Dynamic of complex intracontinental basin: The Central European Basin System (pp. 323 - 344): Springer.

Malaval, M. (2016). "Enregistrement sédimentaire de l'activité diapirique associée à la ride du J bel Azourki, Haut Atlas central, Maroc: Impact sur la géométrie des dépôts et la distribution des faciès des systèmes carbonatés et mixtes du Jurassique inférieur". (Synsedimentary record of diapiric activity related to the J bel Azourki ridge, Central High Atlas, Morocco: Impact on depositional geometries and facies distribution of the Lower J urassic carbonate and mixed systems.). (PhD), Université Bordeaux-Montaigne Pessac, France.

Mansurbeg, H., Morad, D., Othman, R., Morad, S., Ceriani, A., Al-Aasm, I. S., Kolo, K., Spirov, P., Proust, J. N., Preat, A., \& Koyi, H. (2016). Hydrothermal dolomitization of the Bekhme formation (Upper Cretaceous), Zagros Basin, 
Kurdistan Region of Iraq: Record of oil migration and degradation. Sedimentary Geology, 341, 147-162. doi:https://doi.org/10.1016/j.sedgeo.2016.05.015.

Martín-Martín, J. D., Vergés, J., Saura, E., Moragas, M., Messager, G., Baqués, V., Razin, P., Grélaud, C., Malaval, M., Joussiaume, R., Casciello, E., Cruz-Orosa, I., \& Hunt, D. W. (2017). Diapiric growth within an Early Jurassic rift basin: The Tazoult salt wall (central High Atlas, Morocco). Tectonics, 36(1), 2-32. doi: $10.1002 / 2016$ TC004300

Masoumi, S., Reuning, L., Back, S., Sandrin, A., \& Kukla, P. A. (2014). Buried pockmarks on the Top Chalk surface of the Danish North Sea and their potential significance for interpreting palaeocirculation patterns. International Journal of Earth Sciences, 103, 563-578. Mattauer, M., Tapponier, P., \& Proust, F. (1977). Sur les mécanismes de formation des chaines intracontinentales: L'exemple des chaines atlasiques du Maroc. Bull. Soc. géol. France, 77 (7), 521-526.

McManus, K. M., \& Hanor, J. S. (1988). Calcite and iron sulfide cementation of Miocene sediments flanking the West Hackberry salt dome, southwest Louisiana, U.S.A. Chemical Geology, 74(1-2), 99-112. Retrieved from http://www.scopus.com/inward/record.url?eid=2-s2.00024251988\&partnerID $=40 \&$ md5 $=$ ce18c03305891e0136d86e6c8f02bcad

Mehdi, M., Neuweiler, F., \& Wilmsen, M. (2003). Les formations du Lias inférieur du Haut Atlas central de Rich (Maroc): précisions lithostratigraphiques et étapes de l'évolution du bassin. Bulletin de la Société Géologique de France, 174(3), 227-242.

Meyers, W. J. (1974). Carbonate cement stratigraphy of the Lake Valley (Mississippian) Sacramento Mountains, New Mexico. Journal of Sedimentary Petrology, 44, 837-861.

Michard, A., Ibouh, H., \& Charrière, A. (2011). Syncline-topped anticlinal ridges from the High Atlas: A Moroccan conundrum, and inspiring structures from the Syrian Arc, Israel. Terra Nova, 23(5), 314-323. Retrieved from http://www.scopus.com/inward/record.url?eid=2-s2.080052625102\&partnerID =40\&md5=a7e4cbb87f8ca914a1ee3882accbeba4

Moldovany, E. P., \& Lonhmann, K. C. (1984). Isotopic and petrographic record of phreatic diagenesis: Lower Cretaceous Sligo and Cupido Formations. Journal of Sedimentary Petrology, 54, 927-958.

Moore, C. H. (2001). Carbonate Reservoirs: Porosity Evolution and Diagenesis in a Sequence Stratigraphic Framework: Elsevier Science Limited.

Moore, C. H., \& Wade, W. J. (2013). Carbonate Reservoirs: Porosity and diagenesis in a sequence stratigraphic framework: Elsevier Science.

Morad, D., Nader, F. H., Morad, S., Al Darmaki, F., \& Hellevang, H. (2018). Impact of stylolitization on fluid flow and diagenesis on foreland basins: evidence from an Upper Jurasic carbonate gas reservoir, Abu Dhabi, United Arab Emirates. J ournal of Sedimentary Research, 88, 1345-1361.

Moragas, M., Vergés, J., Nalpas, T., Saura, E., Martín-Martín, J.D., Mesager, G. \& Hunt, D. (2017) The Impact of Syn- and Post-Extension Prograding Sedimentation on the Development of Salt-Related Rift Basins and Their Inversion: Clues from Analogue Modelling. Marine and Petroleum Geology, 88, 985-1003.

Moragas, M., Vergés, J., Saura, E., Martín-Martín, J. D., Messager, G., Merino-Tomé, O., Suárez-Ruiz, I., Razin, P., Grélaud, C., Malaval, M., Joussiaume, R., \& Hunt, D. (2018). Jurassic rifting to post-rift subsidence analysis in the Central High Atlas and its relation to salt diapirism. Basin Research, 30(S1), 336-362. doi:doi:10.1111/bre.12223

Morrow, D. W. (1982). Descriptive field classification of sedimentary and diagenetic breccia fabrics in carbonate rocks. Bulletin of Canadian Petroleum Geology, 30(3),

227-229. Retrieved

from 
http://www.scopus.com/inward/record.url?eid=2-s2.00020377756\&partnerID $=40 \&$ md5 =f09dc4f6a42cb890b00cf99b9a000486

Mouttaqi, A., Rjimati, E. C., Maacha, A., Michard, A., Soulaimani, A., \& Ibouh, H. (2011). Les principales mines du Maroc. Retrieved from Rabat:

Petersen, K., \& Lerche, I. (1995). Quantification of thermal anomalies in sediments around salt structures. Geothermics, 24(2), 253-268. doi:http://dx.doi.org/10.1016/0375-6505(94)00051-D

Petersen, K., \& Lerche, I. (1996). Temperature dependence of thermal anomalies near evolving salt structures: importance for reducing exploration risk. Geological Society, London, Special Publications, 100(1), 275-290. doi:10.1144/gsl.sp.1996.100.01.18

Pique, A., Canals, A., Grandia, F., \& Banks, D. A. (2008). Mesozoic fluorite veins in NE Spain record regional base metal-rich brine circulation through basin and basement during extensional events. Chemical Geology, 257, 139-152.

Piqué, A., Charroud, M., Laville, E., Ait Brahim, L., \& Amrhar, M. (2000). The Thethys southern margin in Morocco: Mesozoic and Cenozoic evolution of the Atlas domain. In S. Crasquin \& E. Barrier (Eds.), Peri-Tethys Memoir 5: New data on peri-Tethyan sedimentary basins. (Vol. 182, pp. 93-106). Paris: Mémoires du Muséum National d'Histoire Naturelle.

Poisson, A., Hadri, M., Milhi, A., Julien, M., \& Andrieux, J. (1998). The Central HighAtlas (Morocco). Litho- and chrono-stratigraphic correlations during Jurassic times between Tinjdad and Tounfite. Origin of Subsidence. In S. Crasquin \& E. Barrier (Eds.), Peri-Tethys Memoir 4: Epicratonic Basins of Peri-Tethyan Platforms (Vol. 179, pp. 237-256). Paris: Mémoires du Muséum National d'Histoire Naturelle.

Poprawski, Y., Basile, C., Jaillard, E., Gaudin, M., \& Lopez, M. (2016). Halokinetic sequences in carbonate systems: An example from the Middle Albian Bakio Breccias Formation (Basque Country, Spain). Sedimentary Geology, 334, 3452. doi:http://dx.doi.org/10.1016/j.sedgeo.2016.01.013

Posey, H.H., Kyle, J.R. (1988). Fluid-rock interactions in the salt dome environment: an introduction and review. Chemical Geology, 74, 1-24.

Rddad, L., Mouguina, E. M., Muchez, P., \& Darling, R. S. (2018). The genesis of the Ali Ou Daoud Jurassic carbonate Zn-Pb Mississippi Valley-type deposit, Moroccan Central High Atlas: Constraints from bulk stable C-O-S, in situ radiogenic $\mathrm{Pb}$ isotopes, and fluid inclusion studies. Ore Geology Reviews, 99, 365-379. doi:https://doi.org/10.1016/j.oregeorev.2018.06.020

Reuning, L., Schoenherr, J., Heimann, A., Urai, J. L., Littke, R., Kukla, P. A., \& Rawahi, Z. (2009). Constraints on the diagenesis, stratigraphy and internal dynamics of the surface-piercing salt domes in the Ghaba Salt Basin (Oman): A comparison to the Ara Group in the South Oman Salt Basin. GeoArabia, 14(3), 83-120. Retrieved from http://www. scopus.com/inward/record.url? eid=2-s2.067650879475\&partnerID $=40 \&$ md $5=0815$ cbebceacf98c042c708841c55231

Sánchez, V., Vindel, E., Martín-Crespo, T., Corbella, M., Cardellach, E., \& Banks, D. A. (2009). Sources and composition of fluids associated with fluorite deposits of Asturias (N Spain). Geofluids, 2009, 338-355

Saura, E., Vergés, J., Martín-Martín, J. D., Messager, G., Moragas, M., Razin, P., Grélaud, C., Joussiaume, R., Malaval, M., \& Homke, S. (2014). Syn-to postrift diapirism and minibasins of the Central High Atlas (Morocco): the changing face of a mountain belt. J ournal of the Geological Society, 171(1), 97-105.

Schindler, C., Hagemann, S. G., Banks, D. A., Mernagh, T., \& Harris, C. (2016). Magmatic hydrothermal fluids at the sedimentary rock-hosted, intrusionrelated Telfer Gold-Copper Deposirs, Paterson Orogen, Western Australia: P$\mathrm{T}-\mathrm{X}$ constrains on the Ore forming fluids. Economic Geology, 111, 099-1126.

Schoenherr, J., Reuning, L., Kukla, P. A., Littke, R., Urai, J. L., Siemann, M., \& Rawahi, Z. (2009). Halite cementation and carbonate diagenesis of intra-salt reservoirs from the Late Neoproterozoic to Early Cambrian Ara Group (South 
Oman Salt Basin). Sedimentology, 56(2), 567-589. Retrieved from http://www.scopus.com/inward/record.url?eid=2-s2.058249125499\&partnerID $=40 \&$ md $5=789$ e639b49791fbbaf0c50b9c52501b6 Sharma, R., \& Srivastava, P. K. (2016). Hydrothermal fluids of magmatic origin. In S. Kumar \& R. N. Singh (Eds.), Modelling of magmatic and allied processes. Switzerland: Springer.

Smith, A. P., Fischer, M. P., \& Evans, M. A. (2012). Fracture-controlled palaeohydrology of a secondary salt weld, La Popa Basin, NE Mexico. In G. I. Alsop, S. G. Archer, A. J. Hartley, N. T. Grant, \& R. Hodgkinson (Eds.), Salt Tectonics, Sediments and Prospectivity (Vol. 363, pp. 107-130): Geological Society of London, Special Publication.

Spötl, C., \& Pitman, J. K. (1998). Saddle (Baroque) Dolomite in Carbonates and Sandstones: A Reappraisal of a Burial-Diagenetic Concept. In S. Morad (Ed.), Carbonate Cementation in Sandstones (Vol. Special Publication 26, pp. 437460): The International Association of Sedimentologists.

Teixell, A., Arboleya, M. L., Julivert, M., \& Charroud, M. (2003). Tectonic shortening and topography in the Central High Atlas (Morocco). Tectonics, 22(5), 1-14. Retrieved from Teixell_et_al_2003.pdf

Teixell, A., Barnolas, A., Rosales, I., \& Arboleya, M. L. (2017). Structural and facies architecture of a diapir-related carbonate minibasin (lower and middle Jurassic, High Atlas, Morocco). Marine and Petroleum Geology, 81, 334-360. doi:http://dx.doi.org/10.1016/j.marpetgeo.2017.01.003

Tesón, E., \& Teixell, A. (2008). Sequence of thrusting and syntectonic sedimentation in the eastern Sub-Atlas thrust belt (Dadès and Mgoun valleys, Morocco). International J ournal of Earth Sciences, 97(1), 103-113. doi:10.1007/s00531006-0151-1

Veizer, J., Ala, D., Azmy, K., Bruckschen, P., Buhl, D., Bruhn, F., Carden, G. A. F., Diener, A., Ebneth, S., Godderis, Y., Jasper, T., Korte, C., Pawellek, F., Podlaha, O. G., \& Strauss, H. (1999). 87Sr/86Sr, $\delta 13 \mathrm{C}$ and $\delta 180$ evolution of Phanerozoic seawater. Chemical Geology, 161(1), 59-88. doi:https://doi.org/10.1016/S0009-2541(99)00081-9

Vendeville, B. C., \& Jackson, M. P. A. (1992). The rise of diapirs during thin-skinned extension. Marine and Petroleum Geology, 9(4), 331-354. Retrieved from http://www.sciencedirect.com/science/article/pii/026481729290047I

Vergés, J., Moragas, M., Martín-Martín, J. D., Saura, E., Razin, P., Grélaud, C., Malaval, M., Joussiaume, R., Messager, G., Sharp, I., \& Hunt, D. W. (2017). Salt tectonics in the Atlas mountains of Morocco. In J. I. Soto, J. Flinch, \& G. Tari (Eds.), Permo-Triassic Salt Provinces of Europe, North Africa and the Atlantic Margins: Tectonics and hydrocarbon potential (pp. 263-280): Elsevier.

Warren, J. (2000). Dolomite: occurrence, evolution and economically important associations. Earth-Science Reviews, 52(1-3), 1-81. doi:10.1016/s00128252(00)00022-2

Wilmsen, M., \& Neuweiler, F. (2008). Biosedimentology of the Early Jurassic postextinction carbonate depositional system, central High Atlas rift basin, Morocco. Sedimentology, 55(4), 773-807. Retrieved from http://www.scopus.com/inward/record.url?eid=2-s2.047649117591\&partnerID $=40 \&$ md5=8dbbb5f28a9de51b603aec1292f862df 


\section{9. $\quad$ Figures and figure captions}

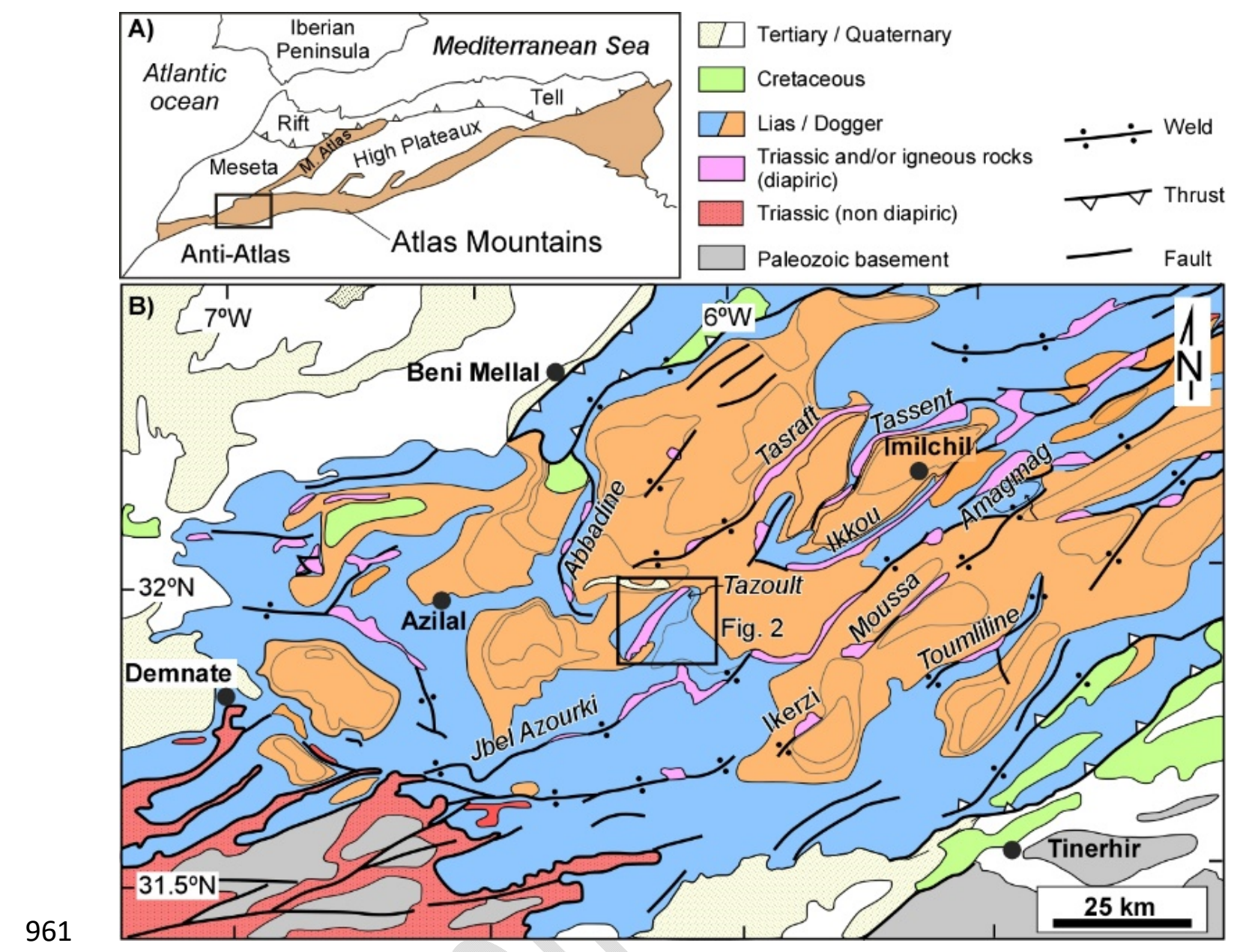

962 Fig. 1. A) Geographic map of North Africa showing the location of the Atlas Mountains. B) Geological map

963 of the central High Atlas (square in A) showing the distribution of diapirs (pink) and welds and the location

964 of the Tazoult salt wall (square) (Modified from Moragas et al., 2017). 

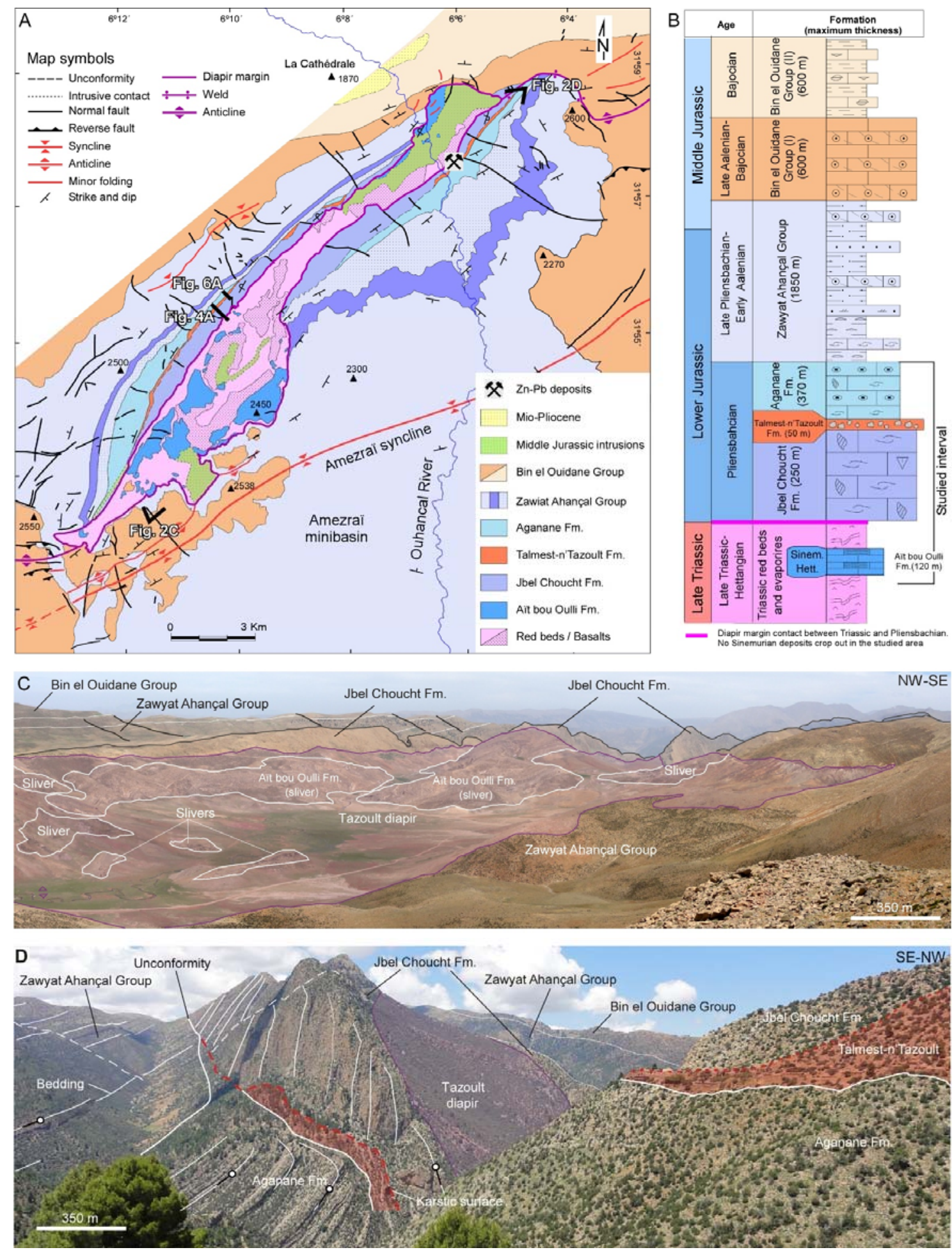

966 Fig. 2. A) Geological map and B) stratigraphy of the Tazoult salt wall (modified from Martín-Martín et al.,

967 2017). C) Panoramic view of the southwester Tazoult salt wall showing the distribution of Hettangian-

968 Lower Sinemurian carbonate slivers embedded in the Triassic deposits. D) Panoramic view of the NE

969 Tazoult salt wall showing the sedimentary succession that crops out in the southern flank of the structure

970 (Modified from Martín-Martín et al., 2017). 

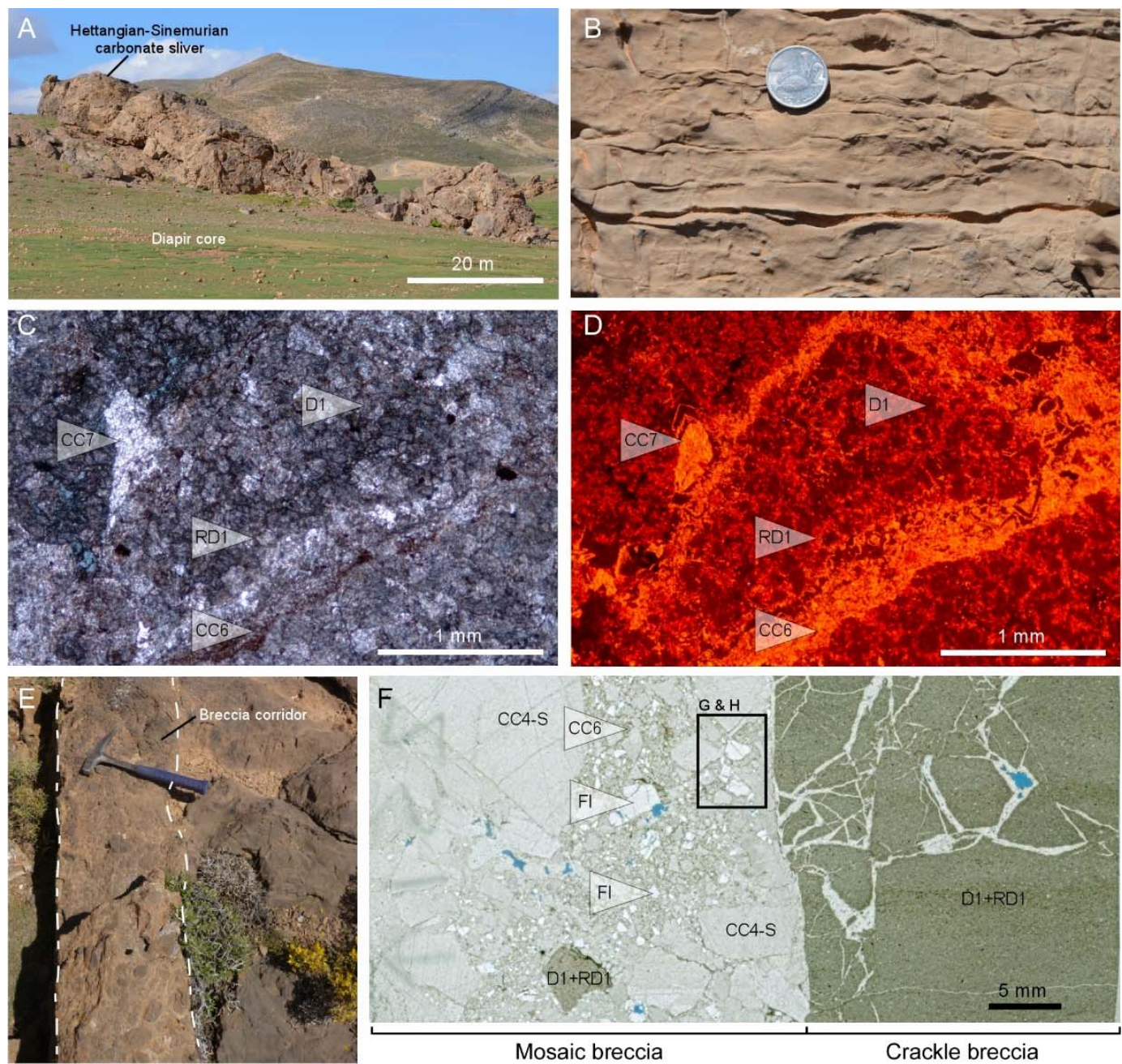

Mosaic breccia

Crackle breccia
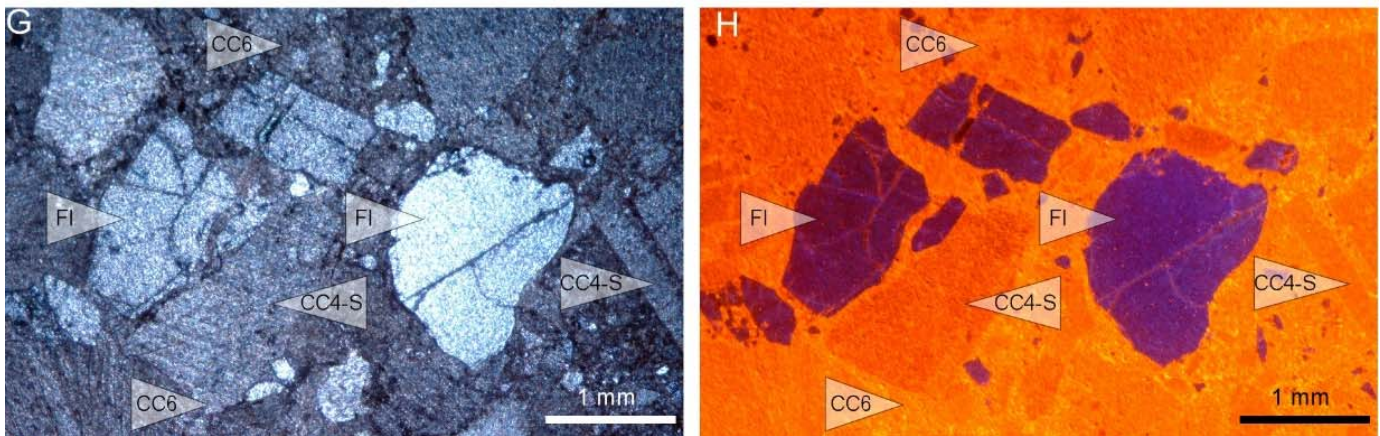

973 Fig. 3 A) Field view of an Aït bou Oulli sliver embedded in the Triassic core rocks. B) Close view of the

974 former showing the typical depositional lamination of the Aït bou Oulli host rocks. C) Cross-polarized light

975 and D) cathodoluminescence photomicrographs of the host carbonates (D1) affected by an early replacive

976 dolomitization (RD1), and showing two generations of calcite cements (CC6 and CC7). E) Field view of the

977 breccia corridor affecting the Aït bou Oulli slivers. F) Thin section of the breccia showing well-

978 differentiated mosaic and crackle textures. G) Cross-polarized light and H) cathodoluminescence

979 photomicrographs of the mosaic breccia (square in F) showing clasts of the host rock (D1+RD1), calcite cement (CC4-S), and fluorite cement (FI) engulfed by late calcite cement (CC6). 

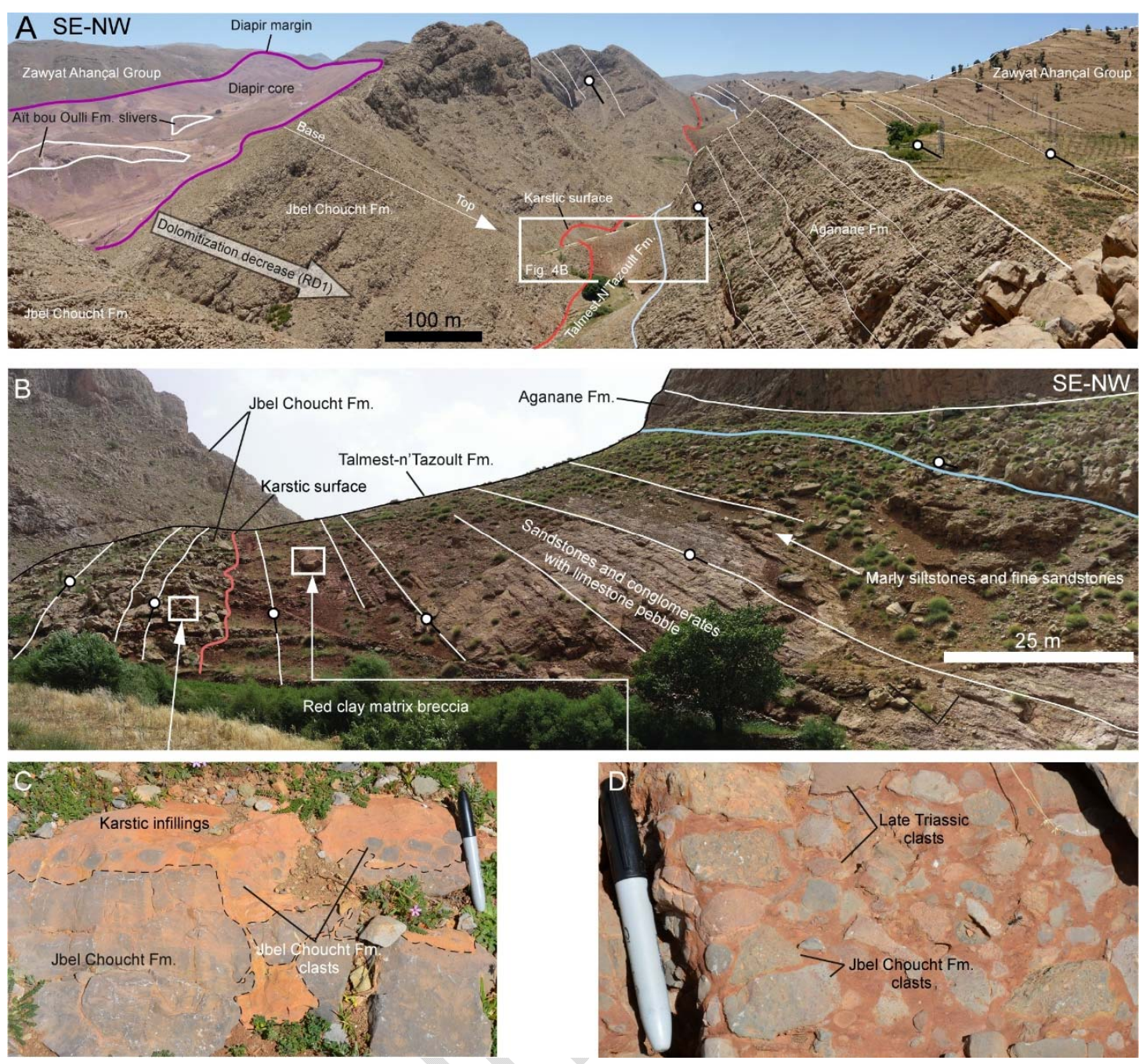

983 Fig. 4 A) Interpreted panoramic view of the north flank of the Tazoult salt wall showing the Jbel Choucht

984 Pliensbachian carbonate platform and the Talmest-n'Tazoult Fm. B) Interpreted detailed panoramic view

985 of the north flank of the Tazoult salt wall showing the karst affecting the top of the Jbel Choucht platform

986 carbonates, and the overlying Talmest-N'Tazoult deposits. C) Close view of the karstic pockets at top of

987 the Jbel Choucht Fm. filled by karstic sediments and Jbel Choucht Fm. clasts. D) Close view of the Talmest-

$988 \quad$ N'Tazoult breccia showing the Jbel Choucht limestones clast and Triassic sandstones clasts. 


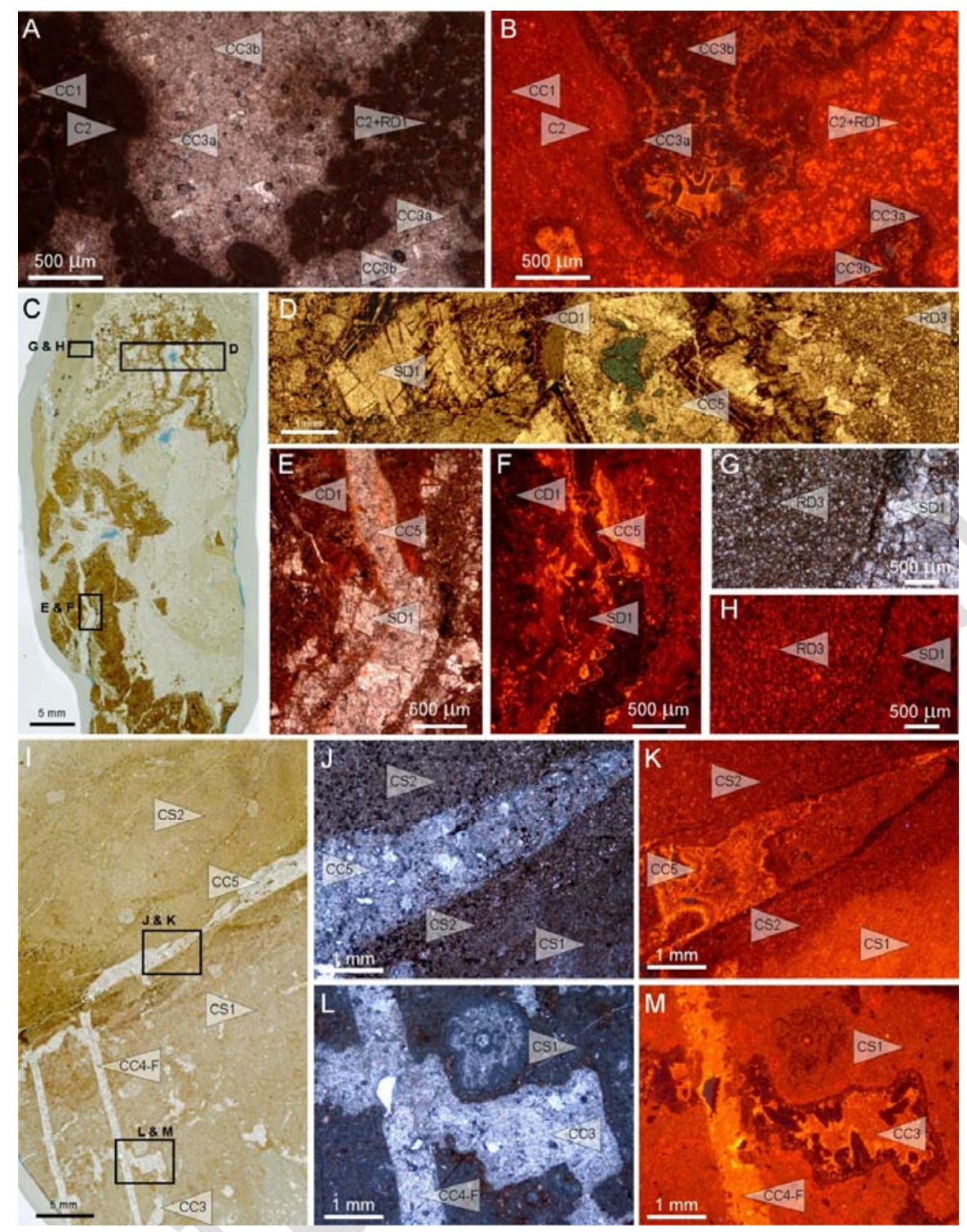

991 Fig. 5 A) Cross-polarized light and B) cathodoluminescence photomicrographs of the Pliensbachian Jbel 992 Choucht carbonates (C2 and CC1) showing the early replacive dolomite 1 (RD1), and calcite cement 3 993 (CC3). Note the change in shape in CC3 crystals from bladed (CC3a) to mosaic (CC3b). C) Thin section scan 994 and D) optical photomicrographs showing the replacive dolomite 3 (RD3) and saddle dolomite (SD1) in 995 karstic sedimentary fillings and vug pores. E) Cross-polarized light and F) cathodoluminescence 996 photomicrographs showing the saddle dolomite (SD1) crystal mosaics predating fractures filled with 997 calcite cement (CC5). Note that SD1 is partially calcitized (CD1). G) Cross-polarized light and H) 998 cathodoluminescence photomicrographs showing the replacive dolomite (RD3) and saddle dolomite 999 (SD1). I) Thin section scan of the karstic sediments showing two types of fillings (CS1 and CS2) and three 1000 calcite cements filling vuggy porosity (CC3) and two fractures sets (CC4-F and CC5). J) Cross-polarized light and K) cathodoluminescence photomicrographs of the karstic sediments (CS1 and CS2) showing the calcite cement CC5 filling a fracture (picture location in I). L) Cross-polarized light and M) cathodoluminescence photomicrographs of the karstic sediments (CS1) showing vug pore filled with calcite cement CC3 and a late fracture filled with calcite cement CC4-F. 

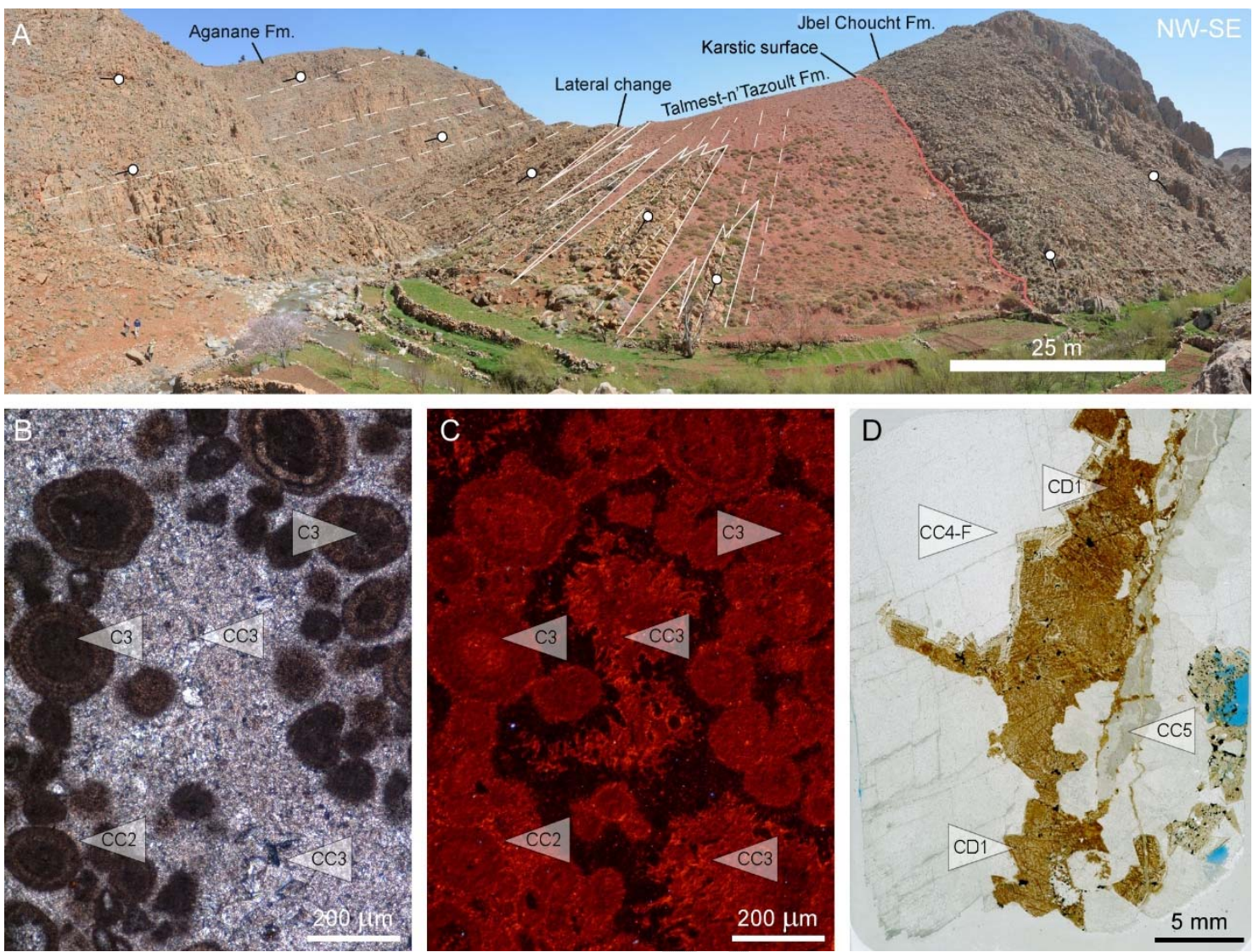

1006 Fig. 6. A) Interpreted panoramic view of the northern flank of the Tazoult salt wall showing the lateral 1007 transition from the Talmest-n'Tazoult breccias to Aganane limestones. B) Cross-polarized light and C) 1008 cathodoluminescence microphotographs of the Aganane Fm. limestones (C3) with interparticle porosity 1009 rimmed by calcite cement CC2 and filled by CC3. D) Thin section the Aganane Fm. limestones showing a 1010 fracture filled by CC4-F, CC5 and SD1. Note that SD1 are completely calcitized to CD1. 


\begin{tabular}{|c|c|c|c|c|c|c|c|c|c|c|c|}
\hline 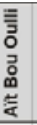 & 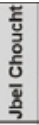 & 范 & 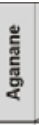 & $\begin{array}{l}\text { Formations Stages } \\
\text { Sediments \& } \\
\text { Diagenetic phases }\end{array}$ & $\begin{array}{c}\text { Pre-Stage } \\
1\end{array}$ & Stage 1 & Stage 2 & Stage $3-4$ & Stage 5 & Stage 6 & Stage 7 \\
\hline \multirow[t]{3}{*}{$x$} & & & & Aït Bou Oulli Fm dolomites (D1) & -- & & & & & & \\
\hline & $x$ & & & Jbel Choucht Fm limestones (C2) & & - & & & & & \\
\hline & $x$ & & & Calcite cement 1 (CC1) & & - & & & & & \\
\hline$x$ & $x$ & & & Replacive dolomite 1 (RD1) & & -- & & & & & \\
\hline \multirow[t]{12}{*}{$X$} & $x$ & $x$ & $\mathrm{X}$ & Fracturing & & $1=-$ & & $=-$ & \multicolumn{2}{|c|}{ - } & - - - \\
\hline & $x$ & $x$ & & Karstic sediment 1 (CS1) & & & - & & & & \\
\hline & $x$ & $x$ & & Karstic sediment 2 (CS2) & & & - & & & & \\
\hline & & $x$ & & Talmest-n'Tazoult Fm breccias & & & ーーーーー & & & & \\
\hline & & & $x$ & Aganane $\mathrm{Fm}$ limestones $(\mathrm{C} 3)$ & & & & - & & & \\
\hline & & & $x$ & Calcite cement $2(\mathrm{CC} 2)$ & & & & & & & \\
\hline & & & $x$ & Karstic sediment $3(\mathrm{CS} 3)$ & & & & - & & & \\
\hline & & & $x$ & Replacive dolomite 2 (RD2) & & & & $=-$ & & & \\
\hline & $x$ & $x$ & $x$ & Calcite cement 3 (CC 3 ) & & & & - & & & \\
\hline & $x$ & & & Replacive dolomite 3 (RD3) & & & & & - & & \\
\hline & $x$ & $x$ & $x$ & Saddle dolomite 1 (SD1) & & & & & $-=$ & & \\
\hline & $x$ & $x$ & $x$ & Calcite cement 4 (CC4-F) & & & & & - & & \\
\hline $\mathrm{x}$ & & & & Calcite cement 4 (CC4-S) & & & エーーーーー & ーーーーーーー & & & \\
\hline \multirow[t]{3}{*}{$\mathrm{x}$} & & & & Fluorite (FI) & & & \multicolumn{4}{|c|}{ 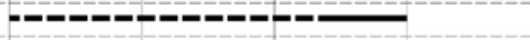 } & \\
\hline & & & & Gabbro intrusions & & & & & & Ini & \\
\hline & $x$ & $x$ & $x$ & Calcite cement 5 (CC5) & & & & & & $=-\overline{-}$ & \\
\hline \multirow[t]{2}{*}{$\mathrm{x}$} & & & & Calcite cement 6 (CC6) & & & & & & $-=-$ & \\
\hline & & & & Mineralization $(\mathrm{Pb})$ & & & & & & $--\square$ & \\
\hline$x$ & $\mathrm{x}$ & & $\mathrm{x}$ & Calcitized dolomite (CD1) & & & & & & & $=-$ \\
\hline$x$ & & $x$ & & Calcite cement 7 ( $\mathrm{CC} 7)$ & & & & & & & -- \\
\hline
\end{tabular}




\section{A) Host rock, karstic sediments and early cements}

Host-rock
Jbel Choucht Fm. (C2)
Karstic sediments
* Karstic sediment 1 (CS1)
* Karstic sediment 2 (CS2)
* Karstic sediment 3 (CS3)
Dolomite
A Replacive dolomite 1 (RD1)
$\Delta$ Replacive dolomite 2 (RD2)
Calcite
$\square$ Calcite cement 2 (CC2)

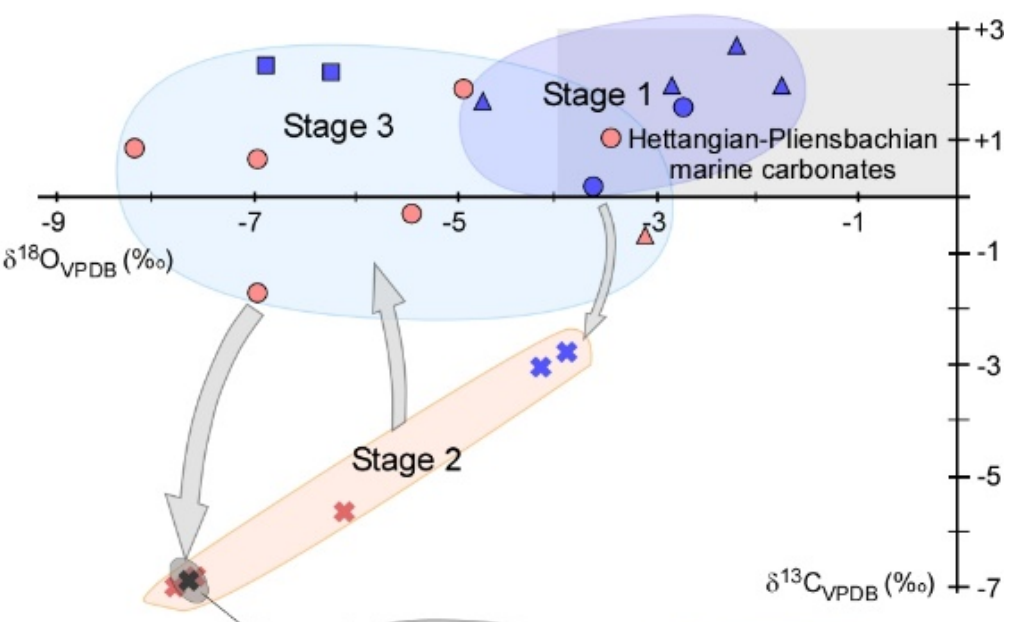

Stage 4

\section{B) Late cements}

\begin{tabular}{l}
\hline Dolomite \\
$\Delta$ Replacive dolomite 3 (RD3) \\
$\Delta$ Saddle dolomite 1 (SD1) \\
Calcite \\
$\square$ Calcite cement 3 (CC3) \\
$\square$ Calcite cement 4 (CC4-F) \\
$\square$ Calcite cement 4 (CC4-S) \\
$\square$ Calcite cement 5 (CC5) \\
$\square$ Calcite cement 6 (CC6) \\
$\square$ Calcitized dolomite 1 (CD1) \\
$\square$ Calcite cement 7 (CC7)
\end{tabular}

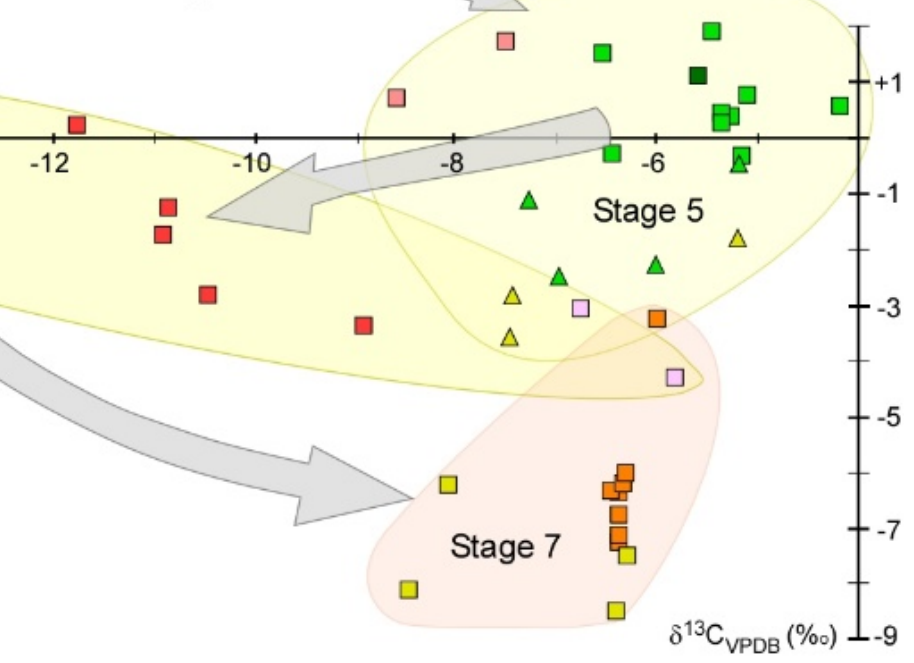

1017 Fig. 8 A) $\delta^{18} \mathrm{O}-\delta^{13} \mathrm{C}$ plot of host rocks, karstic sediments and early cements, and B) $\delta^{18} \mathrm{O}-\delta^{13} \mathrm{C}$ plot of late

1018 cements. Light grey polygon in $\mathrm{A}$ shows the $\delta^{18} \mathrm{O}-\delta^{13} \mathrm{C}$ range of Hettangian to Pliensbachian marine carbonates according to Veizer et al. (1999) and Della Porta et al. (2015). The plots show the isotopic composition of depositional and diagenetic phases arranged according to the defined diagenetic stages (shaded envelopes). Arrows indicate changes of diagenetic realms. 
C2 CC1 RD1 CS1 CS2 C3 CC2 CS3 RD2 CC3 RD3 SD1 CC4-F CC4-S CC5 CC6 CD1 CC7

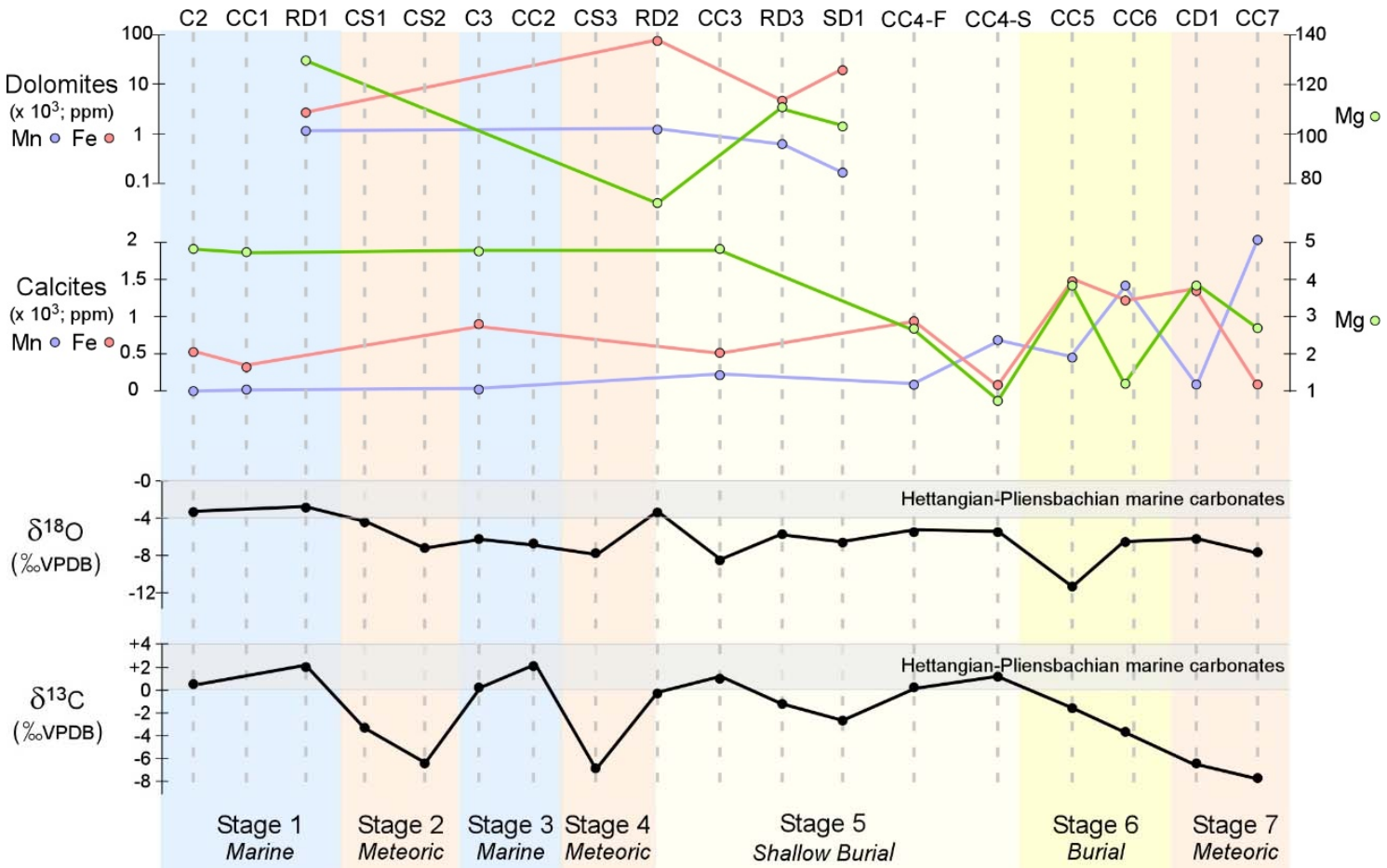

Fig. 9 Elemental composition and stable isotope of the host rocks and diagenetic phases described in the Hettangian to Pliensbachian platform carbonates. Isotopic values for Hettangian-Pliensbachian marine carbonates are according to Veizer et al. (1999). 

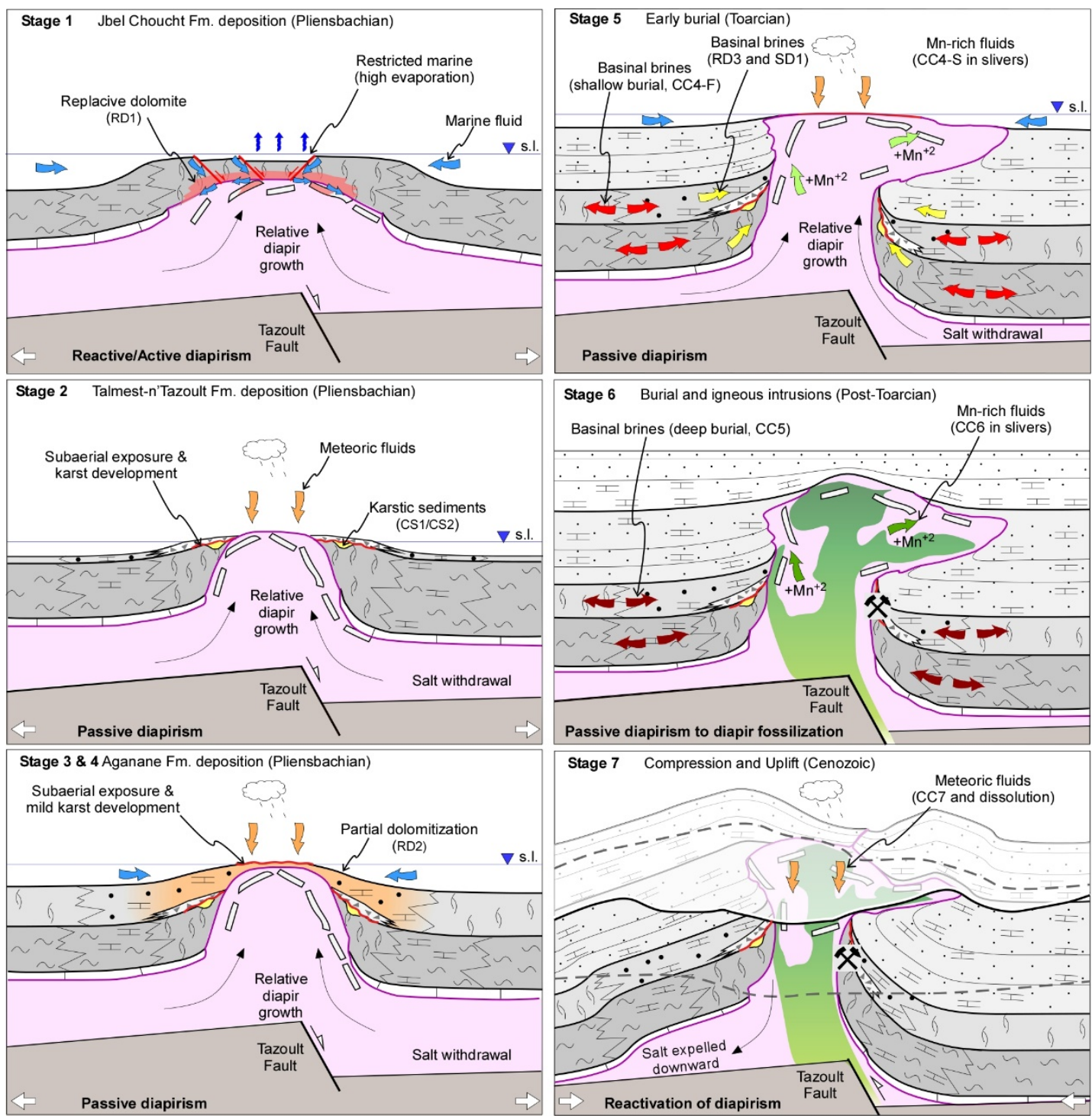

$\square$ Hettangian-early Sinemurian (Aït bou Oulli Fm) $\square$ Late Aalenian-Bathon

Slivers of Hettangian-early Sinemurian

$\square$ Toarcian-Aalenian

E Slope

Г. Lagoon

Upper Triassic-lower Jurassic evaporites,

$\square$ Pliensbachian (Aganane Fm.)

$\because$ Mixed clastic-carbonate

Breccia

clays and basalts

Pliensbachian (Jbel Choucht Fm.)

X Zn-Pb mineralizations

$\sim$ Basin

Paleozoic basement

Igneous intrusion

(6) Carbonate platform

1029 Fig. 10 A) Conceptual model showing the paleohydrological system linked to the evolution of the Tazoult salt wall. The diapiric evolution has been extracted and modified from Martín-Martín, et al. (2017) 